\title{
Salinization and arsenic contamination of surface water in southwest Bangladesh
}

\author{
John C. Ayers ${ }^{1,4^{*}}$, Gregory George ${ }^{1}$, David Fry' , Laura Benneyworth ${ }^{1}$, Carol Wilson ${ }^{1,2}$, Leslie Auerbach 1 , \\ Kushal Roy ${ }^{3}$, Md. Rezaul Karim ${ }^{3}$, Farjana Akter $^{3}$ and Steven Goodbred ${ }^{1}$
}

\begin{abstract}
To identify the causes of salinization and arsenic contamination of surface water on an embanked island (i.e., polder) in the tidal delta plain of SW Bangladesh we collected and analyzed water samples in the dry (May) and wet (October) seasons in 2012-2013. Samples were collected from rice paddies (wet season), saltwater ponds used for brine shrimp aquaculture (dry season), freshwater ponds and tidal channels (both wet and dry season), and rainwater collectors. Continuous measurements of salinity from March 2012 to February 2013 show that tidal channel water increases from $\sim 0.15 \mathrm{ppt}$ in the wet season up to $\sim 20 \mathrm{ppt}$ in the dry season. On the polder, surface water exceeds the World Health Organization drinking water guideline of $10 \mu \mathrm{g} \mathrm{As} / \mathrm{L}$ in $78 \%$ of shrimp ponds and $27 \%$ of rice paddies, raising concerns that produced shrimp and rice could have unsafe levels of As. Drinking water sources also often have unsafe As levels, with $83 \%$ of tubewell and $43 \%$ of freshwater pond samples having $>10 \mu \mathrm{g} \mathrm{As} / \mathrm{L}$. Water compositions and field observations are consistent with shrimp pond water being sourced from tidal channels during the dry season, rather than the locally saline groundwater from tubewells. Irrigation water for rice paddies is also obtained from the tidal channels, but during the wet season when surface waters are fresh. Salts become concentrated in irrigation water through evaporation, with average salinity increasing from $0.43 \mathrm{ppt}$ in the tidal channel source to $0.91 \mathrm{ppt}$ in the rice paddies. Our observations suggest that the practice of seasonally alternating rice and shrimp farming in a field has a negligible effect on rice paddy water salinity. Also, shrimp ponds do not significantly affect the salinity of adjacent surface water bodies or subjacent groundwater because impermeable shallow surface deposits of silt and clay mostly isolate surface water bodies from each other and from the shallow groundwater aquifer. Bivariate plots of conservative element concentrations show that all surface water types lie on mixing lines between dry season tidal channel water and rainwater, i.e., all are related by varying degrees of salinization. High As concentrations in dry season tidal channel water and shrimp ponds likely result from groundwater exfiltration and upstream irrigation in the dry season. Arsenic is transferred from tidal channels to rice paddies through irrigation. Including groundwater samples from the same area (Ayers et al. in Geochem Trans 17:1-22, 2016), principal components analysis and correlation analysis reveal that salinization explains most variation in surface water compositions, whereas progressive reduction of buried surface water by dissolved organic carbon is responsible for the nonconservative behavior of S, Fe, and As and changes in Eh and alkalinity of groundwater.
\end{abstract}

Keywords: Salinization, Arsenic, Aquaculture, Water chemistry, Bangladesh

\section{Introduction}

The Ganges-Brahmaputra-Meghna delta in Bangladesh is the world's largest and most densely populated

\footnotetext{
*Correspondence: john.c.ayers@vanderbilt.edu

${ }^{4}$ Department of Earth \& Environmental Sciences, Vanderbilt University,

PMB 351805, 2301 Vanderbilt Place, Nashville, TN 37235-1805, USA

Full list of author information is available at the end of the article
}

river delta, supporting approximately 160 million people. Water quality in SW Bangladesh is threatened by contamination of water by arsenic, dissolved salts, and pathogens, especially during the long dry season, which lasts from November to May [1]. In the 1990s it was discovered that groundwater from 6 to 10 million tubewells in Bangladesh had As concentrations higher than the World Health Organization (WHO) guideline for drinking water 
of $10 \mu \mathrm{g} / \mathrm{L}$ [2], meaning that more than 57 million people were exposed to unsafe levels of As [3]. Arsenic is a carcinogen to humans and exposure from drinking contaminated water can increase the risk of skin, lung, bladder and kidney cancers, hypertension, diabetes, peripheral vascular disease, and skin lesions [4]. Arsenic present in soil and irrigation (rice paddy) water can also be incorporated into rice, presenting another exposure risk [5-7].

Salinization of surface water and groundwater is another problem in the coastal area of southwest Bangladesh, which similarly leads to negative health effects and reduced agricultural production [8]. Long term exposure to saline drinking water can cause hypertension [9]. In southwest Bangladesh high drinking water salinity has also been linked to relatively high rates of preeclampsia and gestational hypertension, with the latter occurring at higher rates in the dry season than in the wet season [10]. High salinity in irrigation water and soil also decreases crop yields [11]. For example, when irrigation water exceeds 5 ppt salinity, crop yields decrease as much as $50 \%[8]$.

Ayers et al. [12] examined the causes of salinization and arsenic contamination of groundwater resources in Polder 32 in southwest Bangladesh and found that salts in the shallow aquifer groundwater were derived from connate water, whereas sedimentary As was mobilized by reductive dissolution of ferric oxyhydroxides. A related modeling paper also demonstrated that variance in local groundwater salinity could be explained simply by the dilution of connate groundwater having an initial meanannual salinity through the slow, localized recharge of fresh surface water [13]. In a paper on water security for Polder 32, Benneyworth et al. [1] found that local drinking water sources, including groundwater, rainwater, and surface ponds, commonly exceed Bangladesh government guidelines of $2 \mathrm{mS} / \mathrm{cm}$ for specific conductivity (a proxy for salinity) and $50 \mu \mathrm{g} / \mathrm{L}$ As, which raises health concerns. The complementary paper presented here further analyzes the chemical composition of the various surface water sources in Polder 32 (including freshwater pond, rice paddy, shrimp pond, tidal channel, and rainwater), and examines the compositional relationships between groundwater and surface waters and the processes that affect their compositions, with a focus on identifying the sources of dissolved salts and arsenic.

\section{Geographic setting}

The study area is located within the 'abandoned' tidal delta plain of southwest Bangladesh (Fig. 1), which covers $\sim 20,000 \mathrm{~km}^{2}$ in a dense network of tidal channels and intertidal islands previously colonized by mangrove vegetation. This region was initially formed as part of the active Ganges rivermouth in the mid-Holocene, before that river migrated eastward in the late Holocene [14, 15]. Since that time, waning fluvial discharge from the main distributaries [16] has caused the subaerial landscape to be maintained by onshore tidal sediment transport $[17,18]$.

After major floods in 1954 and 1955 followed by years of famine, many of the tidal islands in this area were converted to polders in the 1960s and 1970s by building high earthen embankments around their perimeters for flood control and to increase arable land for rice cultivation [19]. This eliminated regular tidal inundation of the landscape, thereby depriving embanked islands of the sediment normally supplied by these flood waters. Over time subsidence, tidal amplification and channel aggradation have increased the elevation of waters within tidal channels relative to the polders [20,21]. While polder elevation remains above mean sea level, tidal channels located outside the embankments are aggrading to approximately mean high water, making it difficult to keep conduits and connecting channels deep enough to drain the polder [20, 22]. When embankment failures occur, either through storm surges or channel migration, the landscape is exposed to exacerbated tidal flooding and waterlogging, potentially causing salinization of surface water and groundwater. Exchange of water between tidal channels and polders is facilitated by, or results from, average changes in tidal channel surface elevation of 3-4 m between spring low and high tide near Polder 32 [20].

The focus of this study is Polder 32 in Khulna district, Dacope Upazila, about $30 \mathrm{~km}$ south of the city of Khulna and $60 \mathrm{~km}$ north of the Bay of Bengal (Fig. 1). The polder is 19.3 by $7.1 \mathrm{~km}$ with a total area of $68.2 \mathrm{~km}^{2}$ and has a population of roughly 40,000 . It is surrounded by tidal channels, across which lie the Sundarbans mangrove forest in the south, Polder 33 to the east, and Polder 31 to the north and west. Surface sediments and soils in Polder 32 are silt-dominated and clay-rich, forming an impermeable mud cap $[12,13]$.

\section{Potential causes of surface water salinization}

Areas of southwest Bangladesh have experienced chronic problems with surface water salinization. One potential cause of salinization of freshwater ponds and rice paddy water is the dry-season diversion of the Ganges River by the Farraka Barrage that was completed in India in 1975 [16]. This diversion causes a large decrease in dry season discharge and increase in salinity in the Ganges River downstream of the Farraka Barrage and in the Gorai River that branches off the Ganges and was historically the principal dry-season source of freshwater to southwest Bangladesh [23]. With decreased freshwater discharge, the surface water salinity front migrates further inland during the dry season than previously. This study 


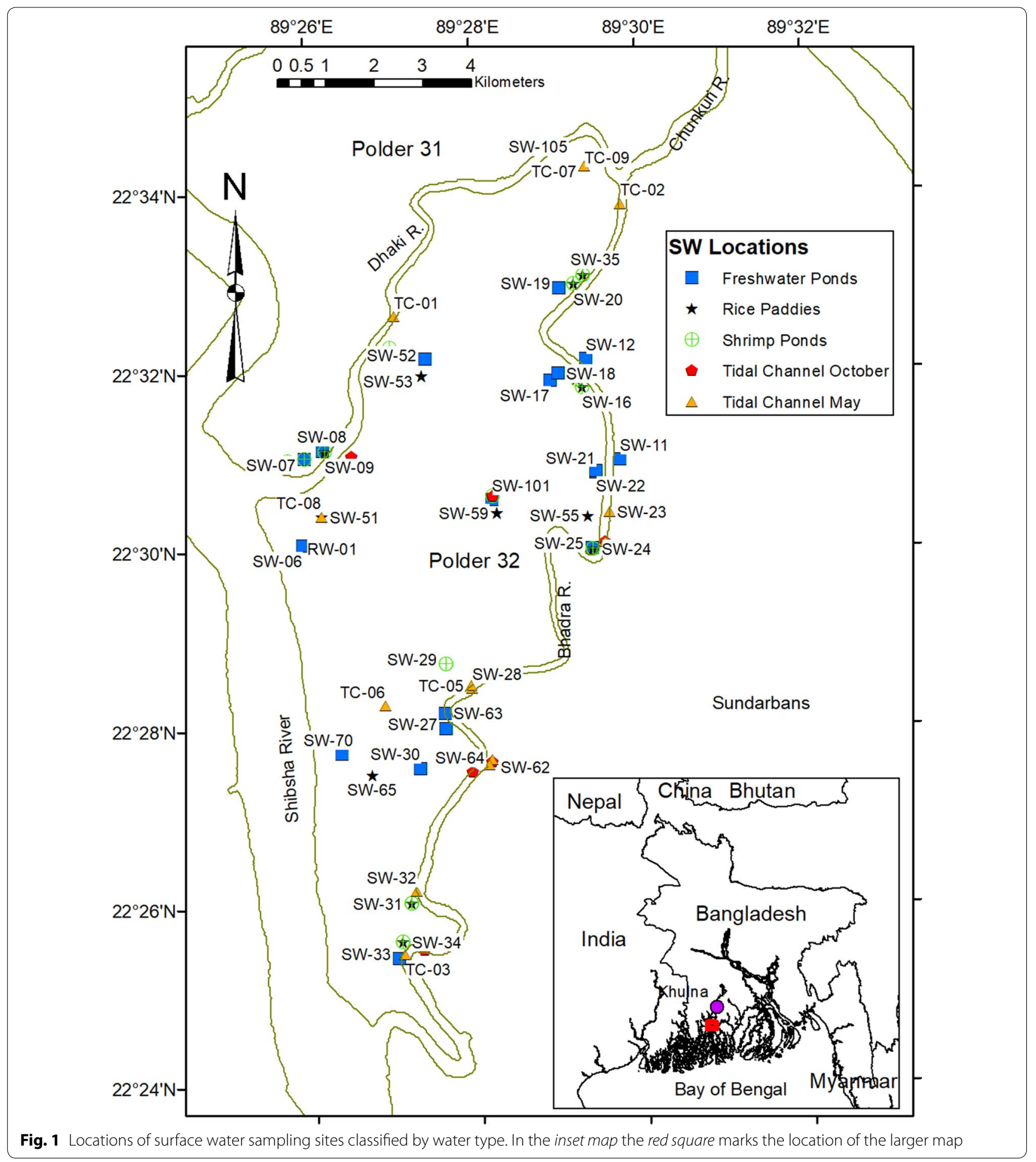

evaluates the impacts of two other potentially important causes of surface water salinization: tidal channel water inundation following embankment breaches, and brine shrimp aquaculture, which requires flooding the landscape with saline ground- or surface-waters.

\section{Tidal channel water inundation}

Polders in southwest Bangladesh are highly susceptible to storm surges during cyclones [24]. Roughly $3 / 4$ of Polder $32\left(\sim 51.2 \mathrm{~km}^{2}\right)$ was inundated for 2 years following the failure of five embankments during Cyclone Aila in 
May 2009 (Fig. 2b). During that time, the polder was submerged to a mean depth of $1 \mathrm{~m}$ for an average of $\sim 10 \mathrm{~h} /$ day [20]. Roughly $40 \mathrm{~cm}$ of silty sediments were deposited on Polder 32 during the 2 years of inundation [20]. Surface water ponds were inundated and contaminated by salts and pathogens, resulting in a severe shortage of safe drinking water [24].

Long-term inundation with brackish water from the surrounding tidal channels and deposition of salt-rich sediments may lead to salinization of surface water bodies in polders. Tidal channel waters in this region are generally saline during the dry season and relatively fresh during the wet season [25]. Sediments deposited during the dry season likely contained saline pore water. On Polder 32, once inundation ceased following embankment repair in approximately May 2011, it presumably would take time for salts to be flushed out of the low permeability sediments; during that time surface water bodies would be expected to have higher than normal salinities due to leaching. This process has not been documented previously. To rectify this, beginning in May 2012 we measured the salinity of water from freshwater ponds and rice paddies on Polder 32 in areas that experienced long-term inundation with brackish tidal channel water and in control areas that were not inundated.

\section{Brine shrimp aquaculture}

During the summer wet season (June to November) rice is grown in paddies in southwest Bangladesh. However, high salinity of surface water and groundwater precludes production of rice in the dry season (December to May). Beginning in 1985, brine shrimp aquaculture was introduced to the region as a profitable use for fallow lands during the dry season [11]. It is now common practice in southwest Bangladesh to rotate land use between shrimp farming in the dry season and salt-tolerant rice farming in the wet season (Fig. 3; [26]). At the time of this study, brine shrimp ponds on Polder 32 were constructed into surface soils and generally located adjacent
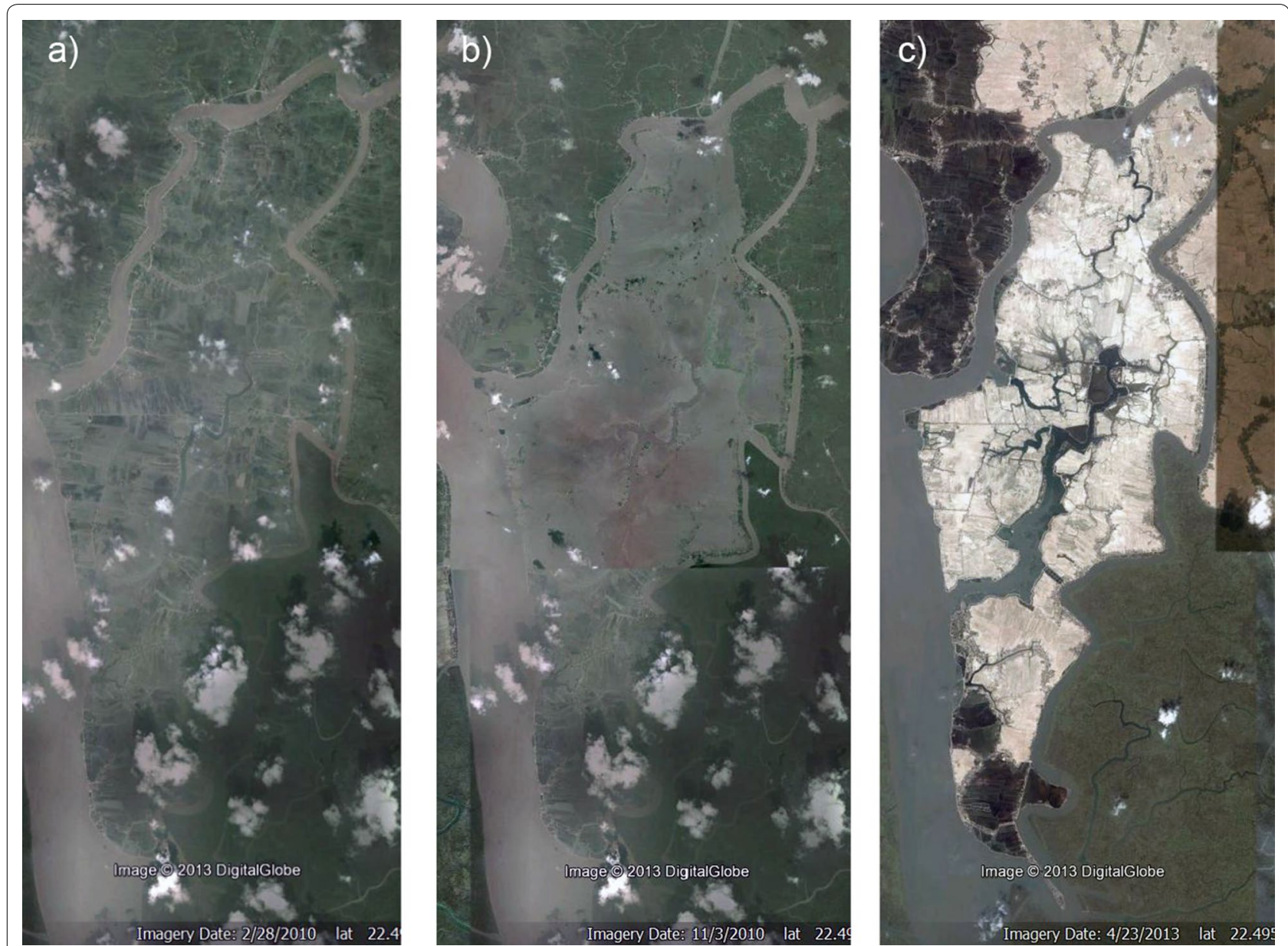

Fig. 2 Google Earth satellite photos of Polder 32. a Wet season, October 13, 2008. b Polder partially inundated after Cyclone Aila, November 3, 2010. c Dry season, April 6, 2013 

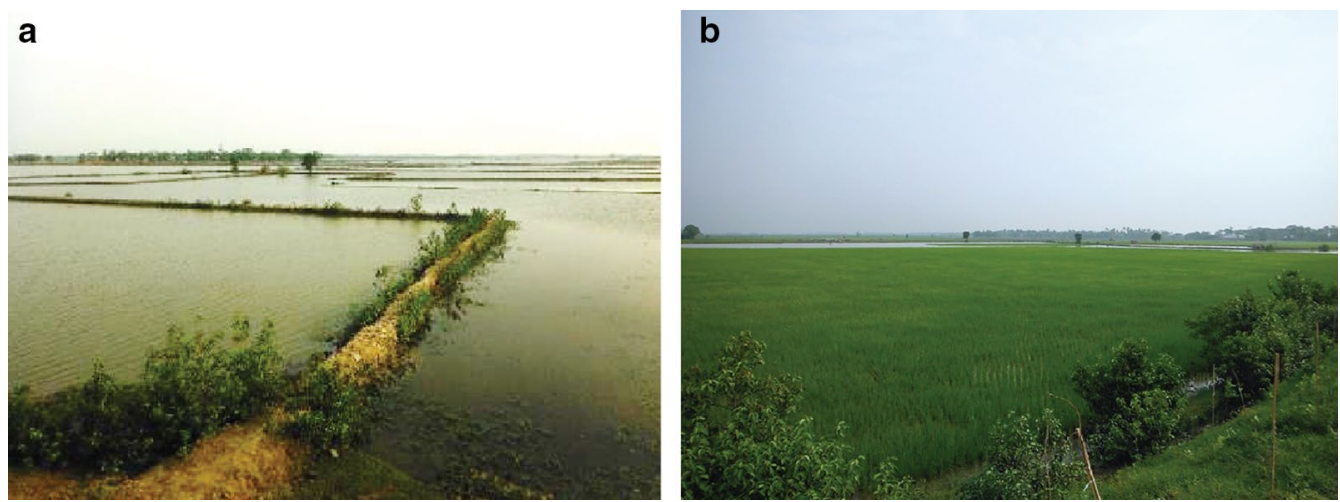

Fig. 3 Photos of the same area of Polder 32, when it was a a Shrimp pond, May 2012, versus b rice paddy, October 2012

to tidal channels to facilitate the exchange of saline water through sluice gates (Fig. 3).

Dry season shrimp farming in southwest Bangladesh has been found to cause salinization of shrimp pond water and soil [27]. Over a 15 year period farms that practiced dry season shrimp farming in southwest Bangladesh showed increases in soil salinity and decreased wet season rice yields [11]. Shrimp farms can also cause salinization of adjacent farmlands if they improperly discharge saltwater during seasonal change-out of brine shrimp aquaculture ponds [26]. However, no studies in this region have evaluated the impacts of dry season brine shrimp aquaculture on water salinity in nearby freshwater ponds or in rice paddies during the wet season.

This study tests the hypotheses that shrimp farming and tidal channel water inundation cause salinization of water in rice paddies and freshwater ponds near Polder 32. In addition, it presents measurements of As concentrations in various surface water types and explores geochemical relationships between surface waters and previously reported groundwater compositions [12].

\section{Potential causes of surface water arsenic contamination}

Although As contamination of groundwater in Bangladesh has been thoroughly studied, less is known about the extent and cause(s) of As contamination of surface water [28]. Generally, arsenic concentrations are expected to be low in oxidized surface waters and can be high in reduced groundwaters [29] because arsenic sorbs to ferric oxydroxides in sediments under oxidizing conditions. One potential source of arsenic is leaching from rocks during chemical weathering. Pyrite in coals seams in the Himalaya is believed to be an important source of As [30,31]. Released ferrous iron is oxidized to form ferric oxyhydroxides that sorb the As and allow it to be transported by rivers, which deposit As-rich sediments in floodplains. Arsenic could be leached from these sediments into water in freshwater ponds, shrimp ponds, or rice paddies. Arsenic in rivers could also be leached from riverbank sediments that have high arsenic concentrations due to discharge of reducing, As-rich groundwater during the dry season [32,33]. Finally, arsenic could derive from groundwater used for irrigation upstream.

\section{Methods}

Samples were collected at the peaks of the dry season (May) and wet season (October) in years 2012 and 2013 throughout the study area shown in Fig. 1. Most sample locations were chosen close to populated areas, principally around the perimeter of Polder 32 where residents had constructed surface ponds and tubewells. Some water samples were also collected on adjacent Polders 31 and 33. Sample locations were measured with a horizontal accuracy of $50 \mathrm{~cm}$ using a Trimble GeoXT 6000 (Table 1). Data was stored and analyzed in ESRI ArcGIS 10.4 .

\section{Field measurements and sample collection}

All field and laboratory methods are described in Ayers et al. [12]. Briefly, in 2012 and May 2013 a Hach Hydrolab 4a was used in the field to measure $\mathrm{pH}$, oxidation-reduction potential Eh in millivolts $(\mathrm{mV})$, temperature in degrees Celsius $\left({ }^{\circ} \mathrm{C}\right)$, and specific conductivity $(\mathrm{SpC})$ in millisiemens per centimeter $(\mathrm{mS} / \mathrm{cm})$. In October 2013 a Hach Hydrolab DS5 was used to make the same measurements.

Platinum electrodes like those in the Hydrolab units typically only respond to a few electroactive species present at concentrations greater than $\sim 10^{-5}$ molal in natural waters, usually only $\mathrm{Fe}^{2+} / \mathrm{Fe}^{3+}[34]$. Thus, Eh measurements are most useful for distinguishing oxic versus anoxic conditions. Comparison of Eh measurements for surface water samples in this study (Table 2) with those of groundwater samples measured using 
Table 1 Sample locations

\begin{tabular}{|c|c|c|c|c|c|c|c|}
\hline Location & Longitude $\left({ }^{\circ}\right)^{\mathbf{a}}$ & Latitude $\left({ }^{\circ}\right)$ & Inundated & Location & Longitude $\left({ }^{\circ}\right)$ & Latitude $\left({ }^{\circ}\right)$ & Inundated \\
\hline RW-04 & 89.438681 & 22.462538 & & sW-32 & 89.453665 & 22.436448 & \\
\hline SW-06 & 89.431902 & 22.501151 & Y & SW-33 & 89.449971 & 22.423910 & $N$ \\
\hline SW-07 & 89.432446 & 22.517320 & $\mathrm{~N}$ & SW-34 & 89.450806 & 22.427044 & Y \\
\hline SW-08 & 89.436222 & 22.518878 & $\mathrm{~N}$ & SW-35 & 89.489165 & 22.551083 & $\mathrm{~N}$ \\
\hline SW-09 & 89.436607 & 22.518719 & N & SW-36 & 89.469382 & 22.460860 & \\
\hline SW-10 & 89.429141 & 22.516978 & & SW-50 & 89.441961 & 22.517735 & \\
\hline SW-100 & 89.449913 & 22.537869 & & SW-51 & 89.435810 & 22.506626 & Y \\
\hline SW-101 & 89.470047 & 22.509296 & & SW-52 & 89.457070 & 22.535705 & Y \\
\hline SW-103 & 89.470224 & 22.509981 & & SW-53 & 89.456294 & 22.532590 & Y \\
\hline SW-105 & 89.483568 & 22.573514 & & SW-55 & 89.489258 & 22.506109 & Y \\
\hline SW-11 & 89.495879 & 22.516575 & $N$ & SW-56 & 89.492793 & 22.501237 & \\
\hline SW-12 & 89.489366 & 22.535426 & $\mathrm{~N}$ & SW-58 & 89.470224 & 22.509981 & \\
\hline SW-13 & 89.488781 & 22.532755 & & SW-59 & 89.471037 & 22.506890 & Y \\
\hline SW-14 & 89.487495 & 22.531589 & Y & SW-60 & 89.471037 & 22.506890 & Y \\
\hline SW-16 & 89.488550 & 22.530110 & Y & SW-61 & 89.455115 & 22.425500 & \\
\hline SW-17 & 89.482202 & 22.531417 & Y & SW-62 & 89.469357 & 22.460383 & \\
\hline SW-18 & 89.483725 & 22.532724 & Y & SW-63 & 89.459957 & 22.469587 & Y \\
\hline SW-19 & 89.484203 & 22.548704 & Y & SW-64 & 89.465396 & 22.458601 & \\
\hline SW-20 & 89.487210 & 22.549411 & Y & SW-65 & 89.445202 & 22.458278 & Y \\
\hline SW-21 & 89.491094 & 22.514213 & Y & SW-70 & 89.439094 & 22.462249 & \\
\hline sW-22 & 89.491073 & 22.514405 & Y & TC-01 & 89.450950 & 22.543850 & \\
\hline sW-23 & 89.493640 & 22.506752 & & TC-02 & 89.496848 & 22.564229 & \\
\hline SW-24 & 89.490216 & 22.499947 & N & TC-03 & 89.451185 & 22.424650 & \\
\hline SW-25 & 89.490032 & 22.500100 & Y & TC-04 & 89.468683 & 22.459838 & \\
\hline SW-27 & 89.460058 & 22.466748 & Y & TC-05 & 89.465426 & 22.474728 & \\
\hline SW-28 & 89.465479 & 22.474240 & & TC-06 & 89.448070 & 22.471190 & \\
\hline SW-29 & 89.460353 & 22.478736 & & TC-07 & 89.489775 & 22.571341 & \\
\hline SW-30 & 89.454787 & 22.459361 & N & TC-08 & 89.435810 & 22.506626 & \\
\hline SW-31 & 89.452650 & 22.434218 & Y & TC-09 & 89.481467 & 22.531006 & \\
\hline
\end{tabular}

a Datum for location is WGS 1984. Freshwater pond and rice paddy sites inundated following Cyclone Aila are indicated with " $Y$ "

the same equipment during the same time periods [12] shows that Eh measurements made with the Hydrolab can distinguish between oxic surface waters and anoxic groundwaters.

Water samples were collected by rinsing a $1 \mathrm{~L}$ bottle, filling it, and immersing the Hydrolab Sonde for field measurements. Rainwater samples were collected in clean glass dishes set out just before a rain event. Next, a syringe with a $0.45 \mu \mathrm{m}$ filter was used to withdraw $30 \mathrm{~mL}$ and transfer it to a polyethylene sample bottle for inductively coupled plasma (ICP) analysis. One drop of concentrated nitric acid $\left(\mathrm{HNO}_{3}\right)$ was added to the bottle. Another $60 \mathrm{~mL}$ was filtered and placed in a sample bottle without acid for ion chromatography (IC) and total organic carbon (TOC) analysis (except for samples collected in May 2012).

Figure 1 lists the five types of surface water sampled and shows sample locations. In total, 44 freshwater pond samples, 18 shrimp pond samples, 18 rice paddy water samples, and 23 tidal channel samples were collected (Table 2). Indicative of seasonal land use, shrimp ponds were present only in the dry season and rice paddies only in the wet season. In October 2013 three rainwater samples were collected.

Continuous measurement of surface water salinity was collected from March 2012 until February 2013 by a Schlumberger Water Service Technologies CTD-Diver deployed in the Bhadra River, a tidal channel close to the Sundarbans and Polder \#32 study areas (see Fig. 1 for location, $22^{\circ} 27^{\prime} 36.9^{\prime \prime} \mathrm{N} 89^{\circ} 28^{\prime} 09.6^{\prime \prime} \mathrm{E}$ ). This Diver (model DI271) measures and records conductivity, temperature, and depth and has the following rated accuracy and precision: pressure measurement range up to $10 \mathrm{~m}$, accuracy of $0.5 \mathrm{~cm}$ and resolution of $0.2 \mathrm{~cm}$; conductivity measurement range of $0-120 \mathrm{mS} / \mathrm{cm}$, with accuracy of $\pm 1 \%$ of the reading with a minimum of $10 \mu \mathrm{S} / \mathrm{cm}$, and resolution 


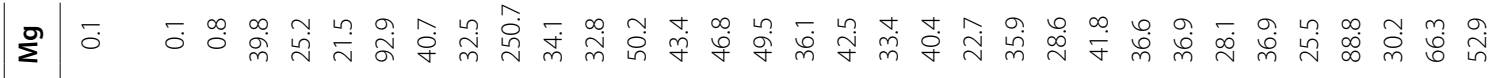

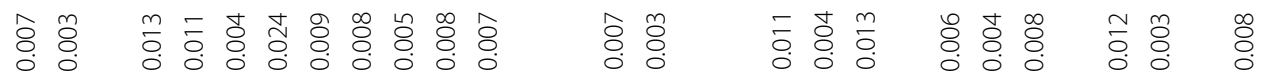

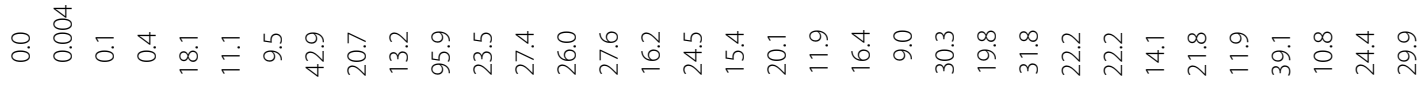

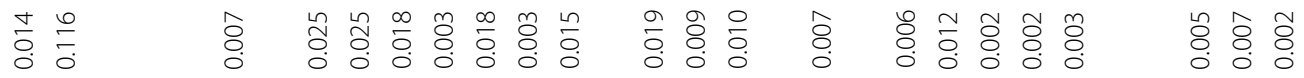
ง 둥 ๓

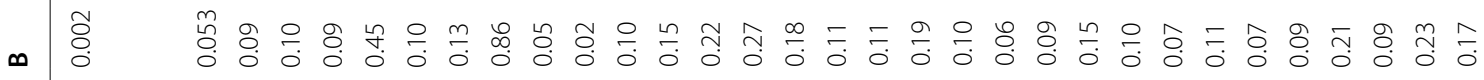
¿ -

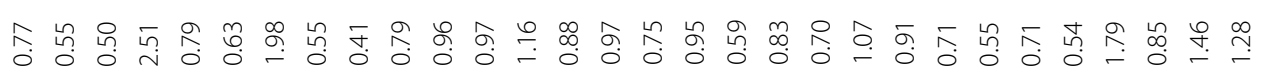

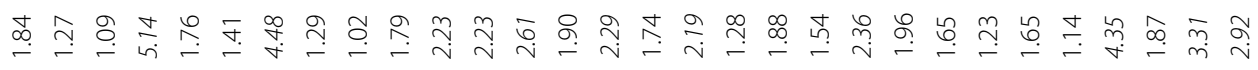

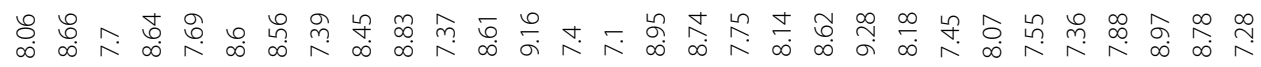
宇

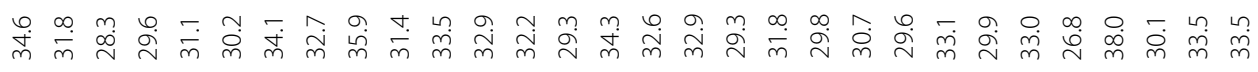
$m$ m $m$ में

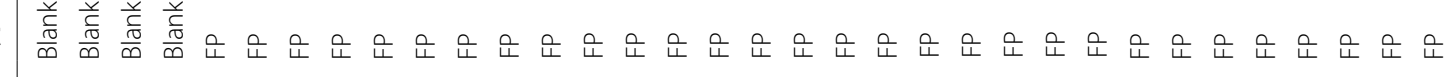

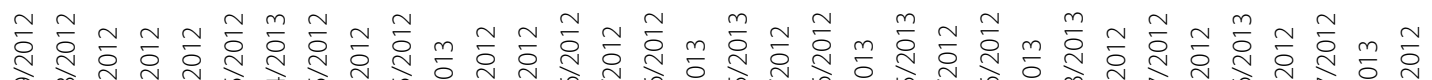

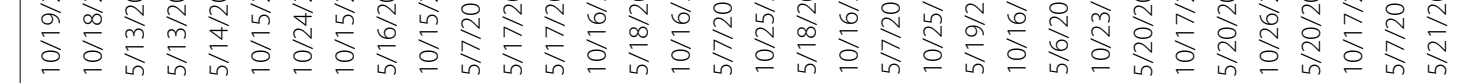

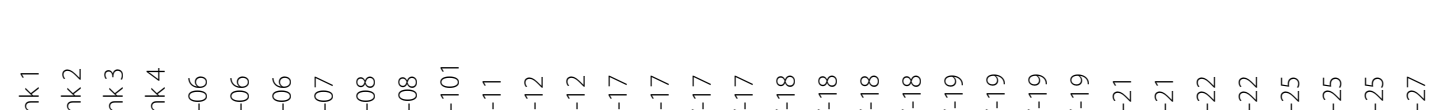

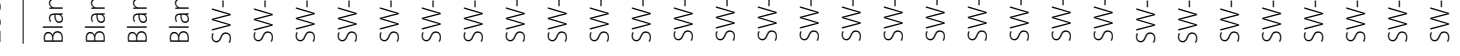




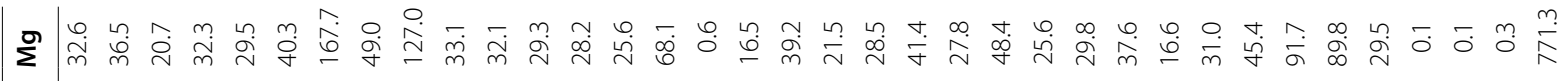

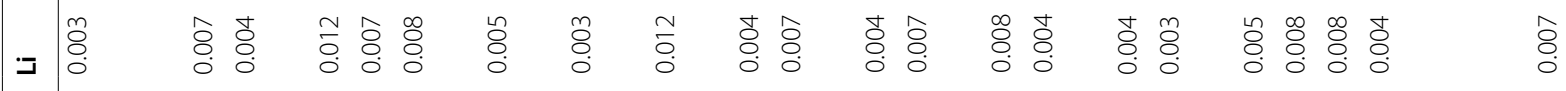

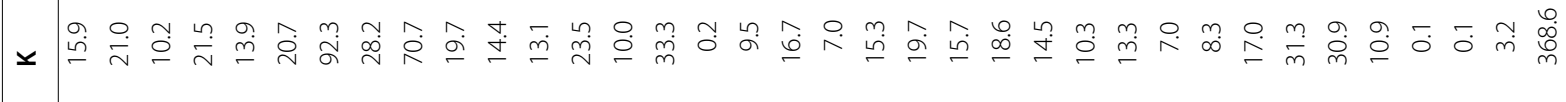
๘ త ๓ ๓ «

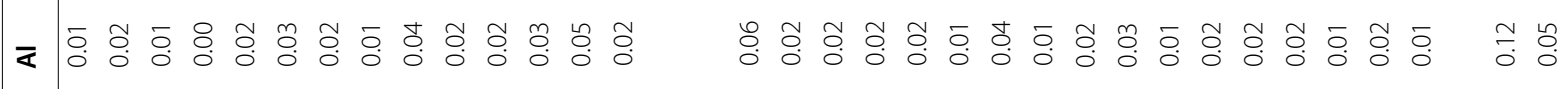

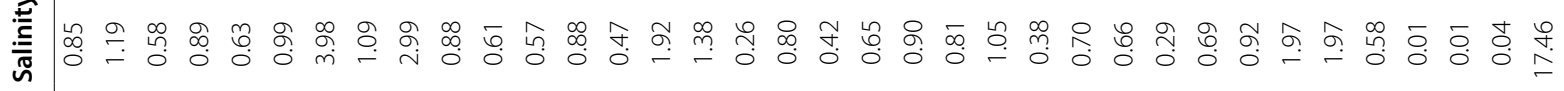
$\bar{\xi}$

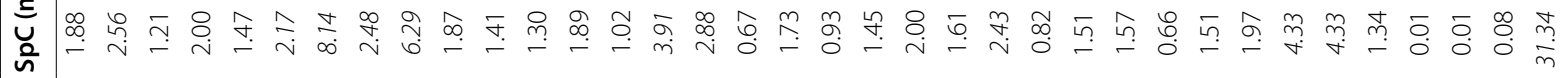

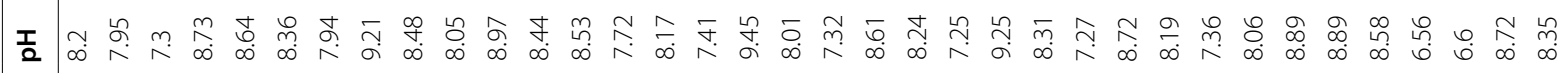

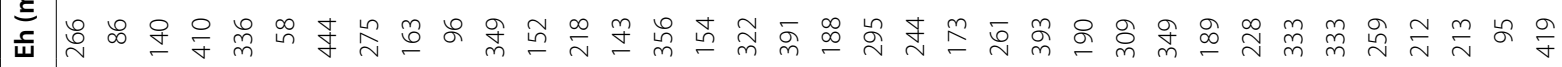

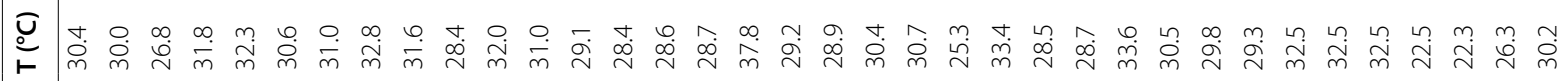

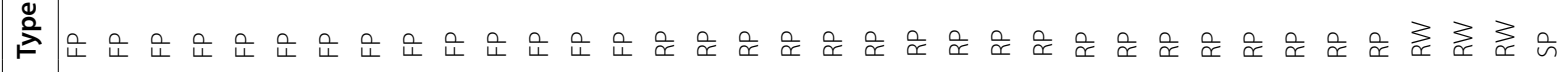

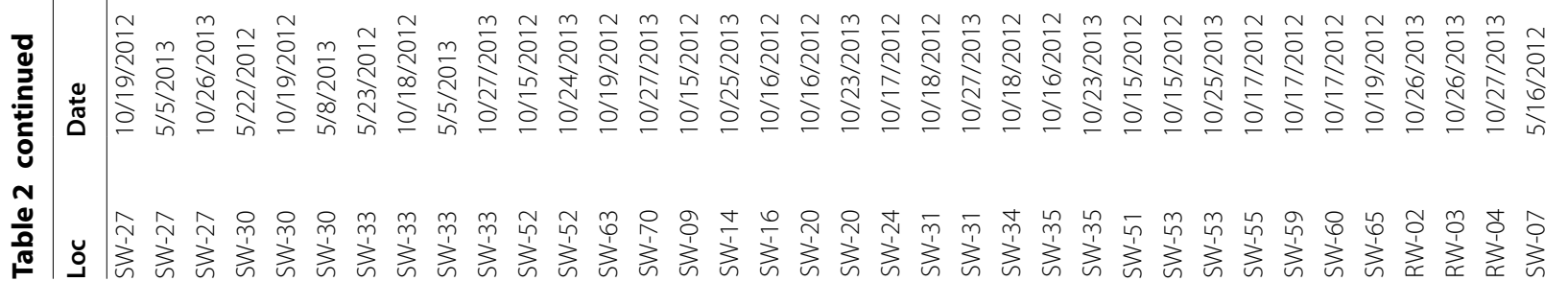




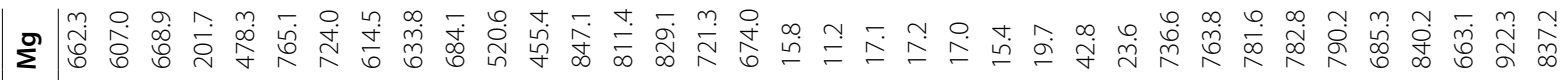

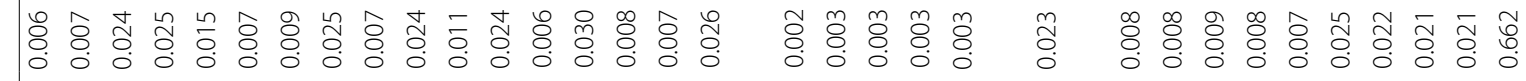

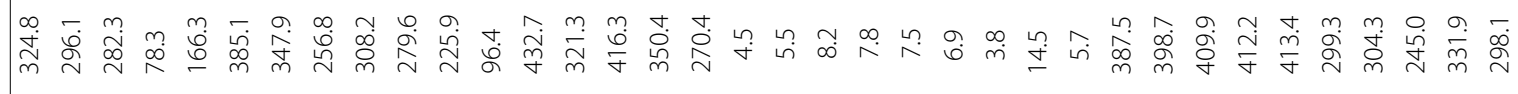

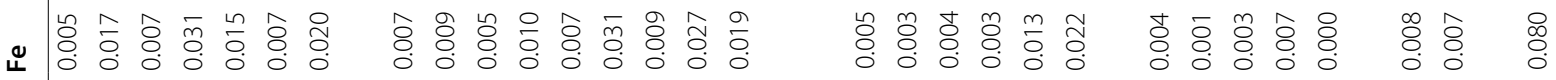

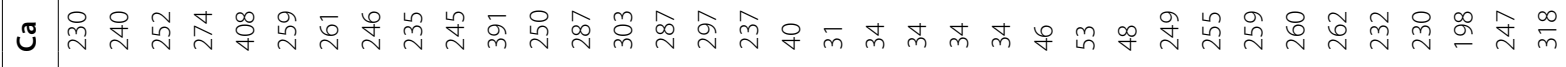
๓

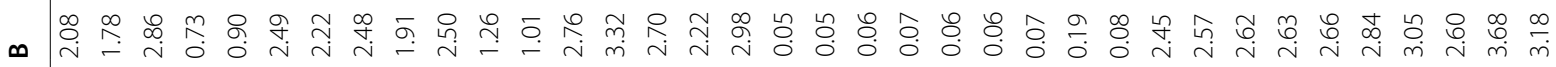
« 区

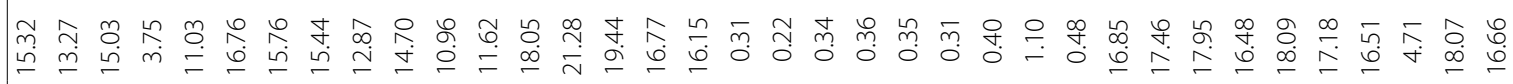

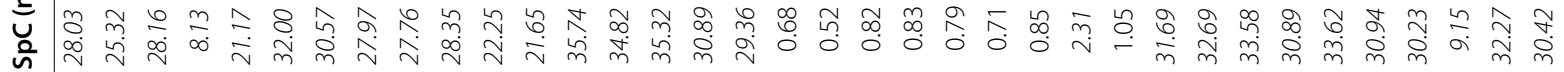
I

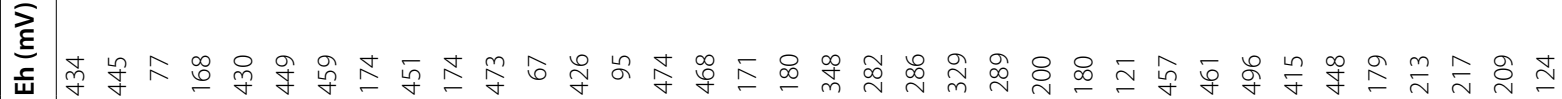

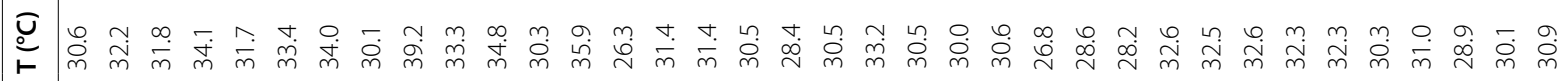

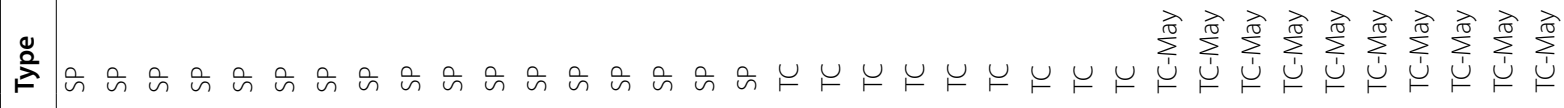

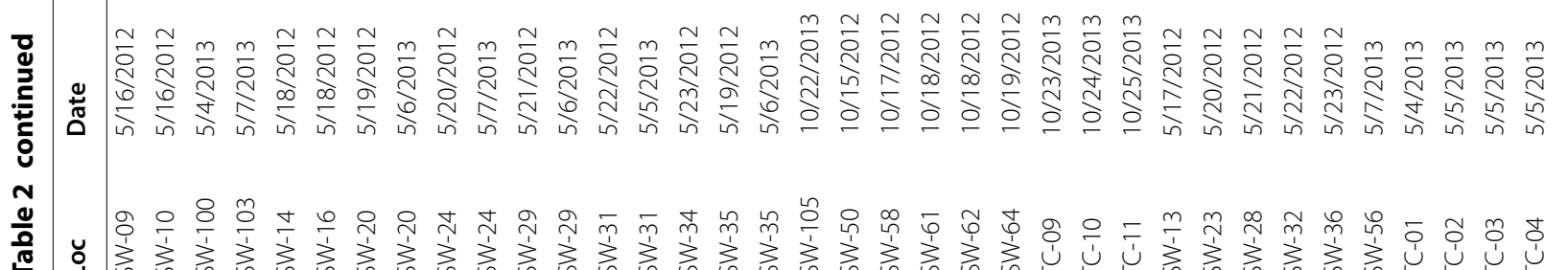




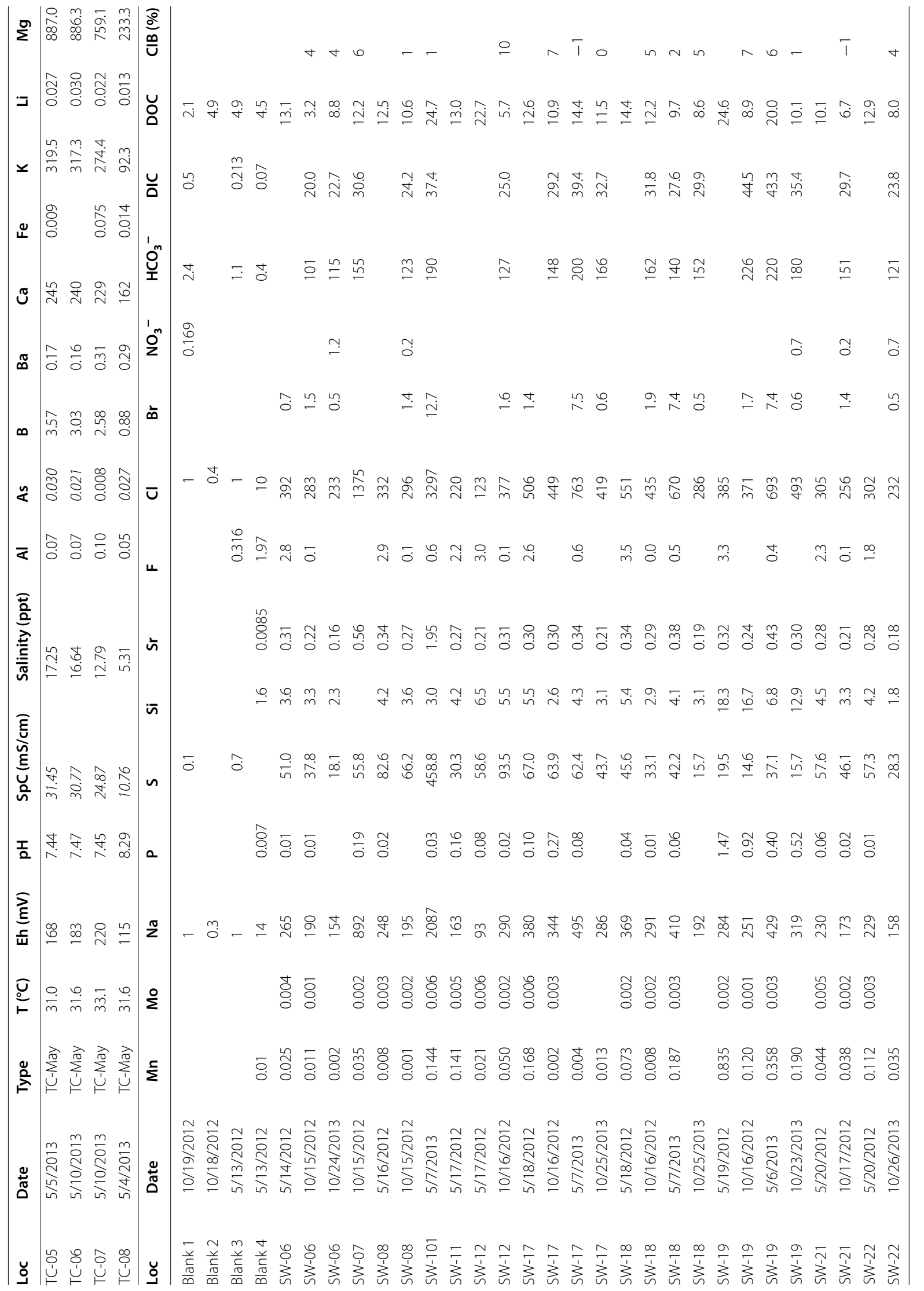




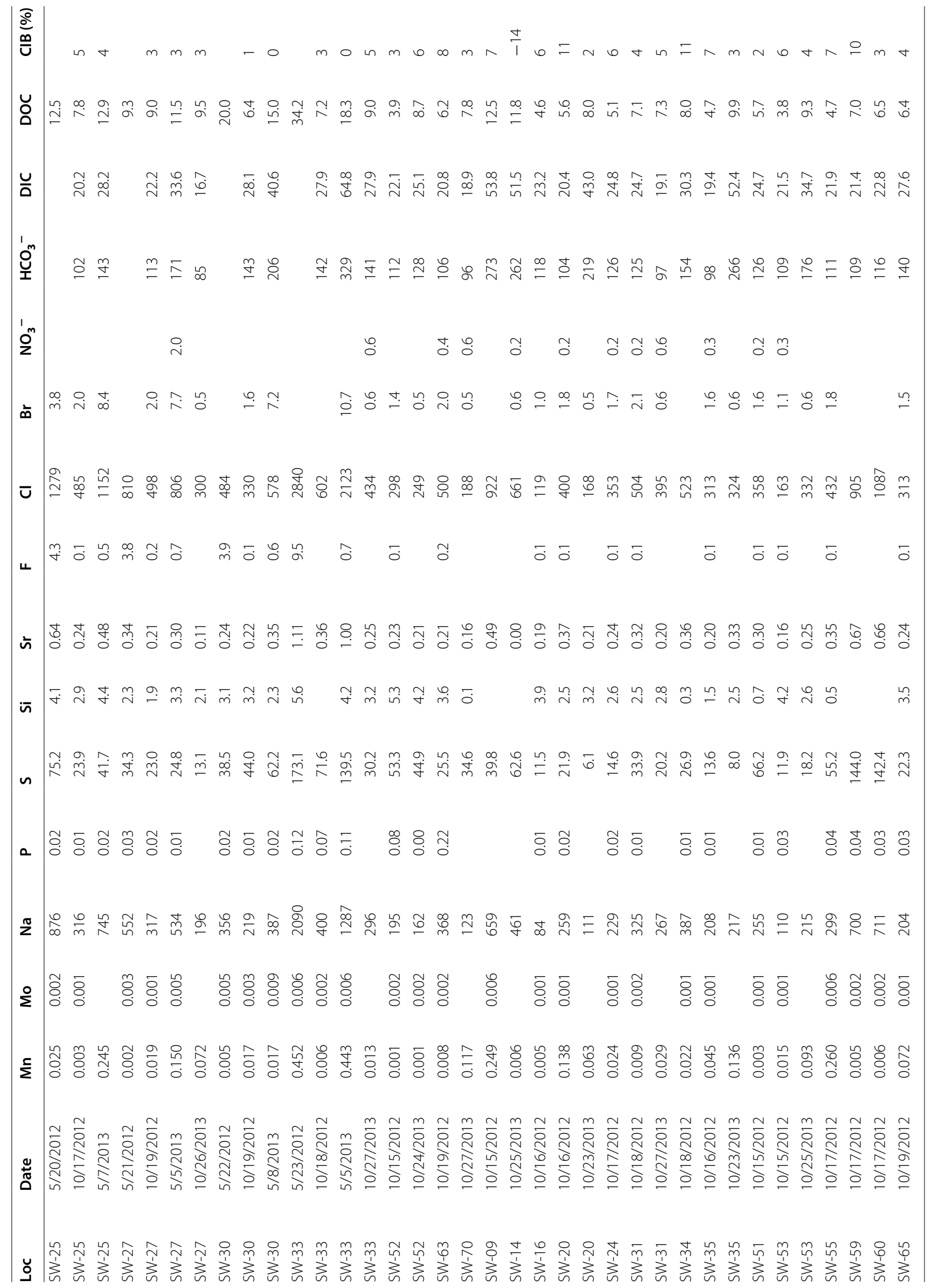




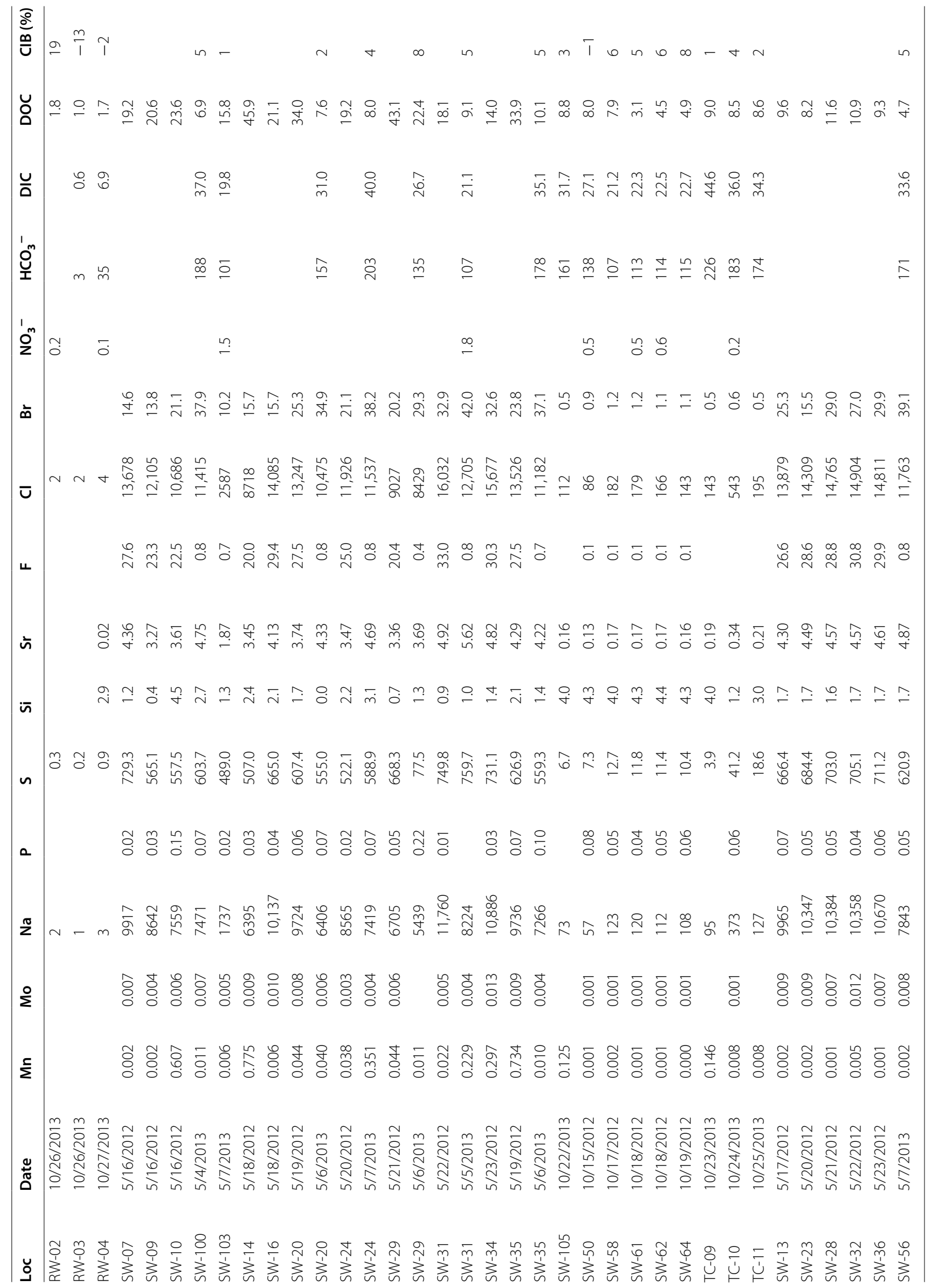




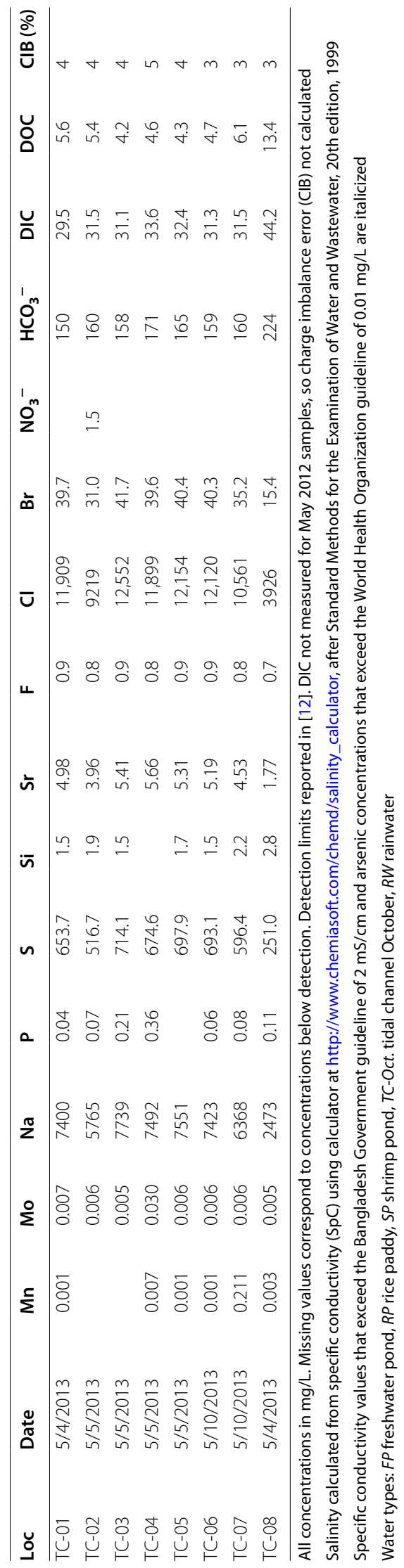


of $0.1 \%$ of reading with minimum of $1 \mu \mathrm{S} / \mathrm{cm}$ for $30 \mathrm{mS} /$ $\mathrm{cm}$ range and $10 \mu \mathrm{S} / \mathrm{cm}$ for $120 \mathrm{mS} / \mathrm{cm}$ range; temperature measurement range -20 to $80{ }^{\circ} \mathrm{C}$, accuracy of $0.1{ }^{\circ} \mathrm{C}$ and resolution of $0.01{ }^{\circ} \mathrm{C}$. The Diver was attached to a $3 / 4$ inch $(1.9 \mathrm{~cm})$ diameter metal rebar mount, deployed and positioned 15-20 cm above the bed of the tidal channel, below the spring tide low water line. Measurements were recorded every $10 \mathrm{~min}$ during the deployment period $(\mathrm{N}=43,832)$. Measured conductivity and temperature was then used to calculate surface water salinity using standard water quality equations (e.g., [35]).

\section{Water chemistry Water analysis}

For all analyses an analytical blank and check standard was run every $10-20$ samples and required to be within $15 \%$ of the specified value. If the maximum concentration in the calibration standards was exceeded, then samples were diluted gravimetrically to within the targeted analytical range.

Acidified aqueous samples were analyzed for metal cation concentrations using a Varian ICP Model 720-ES ICP-OES utilizing EPA Method 6010B. Five-point standard curves were used for an analytical range between approximately 0.1 and $25 \mathrm{mg} / \mathrm{L}$ for trace metals and approximately 0.1 and $500 \mathrm{mg} / \mathrm{L}$ for major ions.

Elements below detection were reanalyzed using a Perkin Elmer Elan 6100 DRC II ICP-MS in both standard and dynamic reaction chamber (DRC) modes. Standard analysis mode was used for all analytes except for As and $\mathrm{Se}$, which were run in DRC mode with $0.5 \mathrm{~mL} / \mathrm{min}$ of oxygen as the reaction gas. Seven-point standard curves were used for an analytical range between approximately 0.5 and $250 \mu \mathrm{g} / \mathrm{L}$ and completed before each analysis.
Analyses of anions were performed on unacidified samples using a Metrohm 881 Compact IC Pro employing ASTM Method D-4327-03. Seven-point calibration curves were generated by dilution of a multi-anion standard at $500 \times, 200 \times, 100 \times, 50 \times, 10 \times, 2 \times$, and $1 \times$ and were accepted with a correlation coefficient of at least 0.995 . A volume of approximately $10 \mathrm{~mL}$ of undiluted sample was loaded for analysis.

Analyses of organic and inorganic carbon were performed on unacidified samples using a Shimadzu model TOC-V CPH/CPN using ASTM Method D-7573-09. Five-point calibration curves, for both dissolved inorganic carbon (DIC) and non-purgeable DOC, were generated for an analytical range between 5 and $100 \mathrm{ppm}$ and were accepted with a correlation coefficient of at least 0.995 . A volume of approximately $20 \mathrm{~mL}$ of undiluted sample was loaded for analysis. DIC analysis was performed first for the analytical blank and standard and then the samples. DOC analysis was carried out separately after completion of DIC analysis. DOC analysis started with addition of $2 \mathrm{M}$ hydrochloric acid to achieve a pH of 2 along with a sparge gas flow rate of $50 \mathrm{~mL} / \mathrm{min}$ to purge inorganic carbon prior to analysis.

\section{Quality assurance/quality control}

Analysis of May 2012 nitrate $\mathrm{NO}_{3}{ }^{-}$and DIC concentrations was compromised due to addition of $\mathrm{HNO}_{3}$ (i.e., unacidified samples were not collected in May 2012). Therefore, results for May $2012 \mathrm{NO}_{3}{ }^{-}$and $\mathrm{HCO}_{3}{ }^{-}$concentrations are not used in the data analysis nor can charge-balance errors or saturation indices be determined for May 2012 samples.

To calculate charge balance errors $\mathrm{PO}_{4}{ }^{3-}$ concentrations were calculated from the $\mathrm{P}$ concentration measured by $\mathrm{ICP}$ and $\mathrm{SO}_{4}{ }^{2-}$ concentrations from $\mathrm{S}$ concentrations

Table 3 Summary of key water quality parameters classified by water type

\begin{tabular}{|c|c|c|c|c|c|c|c|c|c|c|c|c|c|c|c|c|}
\hline \multirow{3}{*}{$\begin{array}{l}\text { Parameter } \\
\text { Number n }\end{array}$} & \multirow{2}{*}{\multicolumn{2}{|c|}{$\begin{array}{l}\text { Blank } \\
4\end{array}$}} & \multirow{2}{*}{\multicolumn{2}{|c|}{$\begin{array}{l}\text { Fresh water } \\
\text { pond } \\
44\end{array}$}} & \multirow{2}{*}{\multicolumn{2}{|c|}{$\begin{array}{l}\text { Rice pad- } \\
\text { dies } \\
18\end{array}$}} & \multirow{2}{*}{\multicolumn{2}{|c|}{$\begin{array}{l}\text { Rain water } \\
3\end{array}$}} & \multirow{2}{*}{\multicolumn{2}{|c|}{$\begin{array}{l}\text { Shrimp } \\
\text { ponds }\end{array}$}} & \multirow{2}{*}{\multicolumn{2}{|c|}{$\begin{array}{l}\text { Tidal chan- } \\
\text { nel Oct. } \\
9\end{array}$}} & \multirow{2}{*}{\multicolumn{2}{|c|}{$\begin{array}{l}\text { Tidal chan- } \\
\text { nel May } \\
14\end{array}$}} & \multirow{2}{*}{\multicolumn{2}{|c|}{$\begin{array}{l}\text { Tube well } \\
81\end{array}$}} \\
\hline & & & & & & & & & & & & & & & & \\
\hline & Avg. & $1 \sigma$ & Avg. & $1 \sigma$ & Avg. & $1 \sigma$ & Avg. & $1 \sigma$ & Avg. & $1 \sigma$ & Avg. & $1 \sigma$ & Avg. & $1 \sigma$ & Avg. & $1 \sigma$ \\
\hline Eh $(m V)$ & & & 273 & 126 & 276 & 77 & 173 & 68 & 325 & 162 & 246 & 78 & 279 & 141 & 69 & 97 \\
\hline $\mathrm{pH}$ & & & 8.2 & 0.6 & 8.2 & 0.7 & 7.3 & 1.2 & 8.1 & 0.4 & 7.8 & 0.8 & 7.4 & 0.4 & 6.9 & 0.4 \\
\hline Salinity (ppt) & & & 1.02 & 0.69 & 0.91 & 0.55 & 0.02 & 0.02 & 14.76 & 3.91 & 0.43 & 0.26 & 15.14 & 4.48 & 3.64 & 2.00 \\
\hline Geom. mean As ( $\mu \mathrm{g} / \mathrm{L})$ & -2.22 & & -2.0 & 0.3 & -2.3 & 0.4 & & & -1.8 & 0.4 & -2.4 & 0.4 & -1.8 & 0.4 & -1.4 & 0.6 \\
\hline Geom. mean S (mg/L) & -0.63 & 0.67 & 1.6 & 0.3 & 1.4 & 0.4 & -0.4 & 0.3 & 2.7 & 0.2 & 1.0 & 0.3 & 2.8 & 0.1 & 0.7 & 0.8 \\
\hline Geom. mean DOC (mg/L) & 0.59 & 0.18 & 1.0 & 0.2 & 0.8 & 0.1 & 0.2 & 0.1 & 1.2 & 0.3 & 0.8 & 0.2 & 0.8 & 0.2 & 1.4 & 0.2 \\
\hline$>10 \mu \mathrm{g} / \mathrm{L} \mathrm{As}$ & & & $41 \%$ & & $22 \%$ & & $0 \%$ & & $78 \%$ & & $11 \%$ & & $71 \%$ & & $83 \%$ & \\
\hline$>50 \mu \mathrm{g} / \mathrm{L} \mathrm{As}$ & & & $2 \%$ & & $0 \%$ & & $0 \%$ & & $11 \%$ & & $0 \%$ & & $7 \%$ & & $47 \%$ & \\
\hline$>2 \mathrm{mS} / \mathrm{cm}$ & & & $36 \%$ & & $28 \%$ & & $0 \%$ & & $100 \%$ & & $11 \%$ & & $100 \%$ & & $100 \%$ & \\
\hline
\end{tabular}


measured by ICP. Measured DIC values were used to calculate concentrations of $\mathrm{HCO}_{3}{ }^{-}$. For samples with complete chemical analyses (excludes May 2012 samples) the average charge-balance error was 3.9\%.

Method detection limits are reported in Ayers et al. [12]. Sample blanks consisting of deionized water were collected in the field and analyzed, yielding method blank sample concentrations that were consistently below analytical detection limits.

\section{Data reduction}

Mineral saturation indices were calculated for select samples using the Spec8 program in the Geochemists Workbench v. 9 and the default thermodynamic database thermo.dat [36]. Principal components analysis in SPSS was used to reduce the number of dimensions (variables) needed to describe the Polder 32 compositional data for surface water (this study) and groundwater samples [12]. Variables that were not normally distributed or had missing values were eliminated, as were samples that were compositional outliers (GW-42). For May (dry season) and October (wet season) data this left 190 samples and 13 variables. When measured concentrations were below detection in the two rainwater samples (RW-02 and RW-03) we substituted the method detection limit for the concentration. The output consisted of loadings (coefficients of the eigenvectors) for the two principal components factors $\mathrm{PC} 1$ and $\mathrm{PC} 2$. Loadings measure the extent to which a factor is associated with a variable [37]. The factor scores for each sample were calculated by normalizing the original variables to standard scores or $\mathrm{z}$ values:

$$
\mathrm{z}=(\mathrm{x}-\mu) / \sigma
$$

where $\mu$ is the mean and $\sigma$ the standard deviation for that variable. The $\mathrm{z}$ value vector was then multiplied by the appropriate coefficient vector.

\section{Results}

Results of water analyses are presented in Table 2, and a summary of key water quality parameters is in Table 3 . Time elapsed between sample collection and analysis on nonacidified samples ranged between 12 and 38 days, but no significant change in measured concentrations of DOC or DIC were observed over time, although nitrate decreased. Furthermore, measurements of DOC in acidified and nonacidified samples were not significantly different.

For each water type, measured concentrations of most elements displayed a lognormal distribution. This was confirmed by transforming the concentrations to their base 10 logarithms and testing for normality using

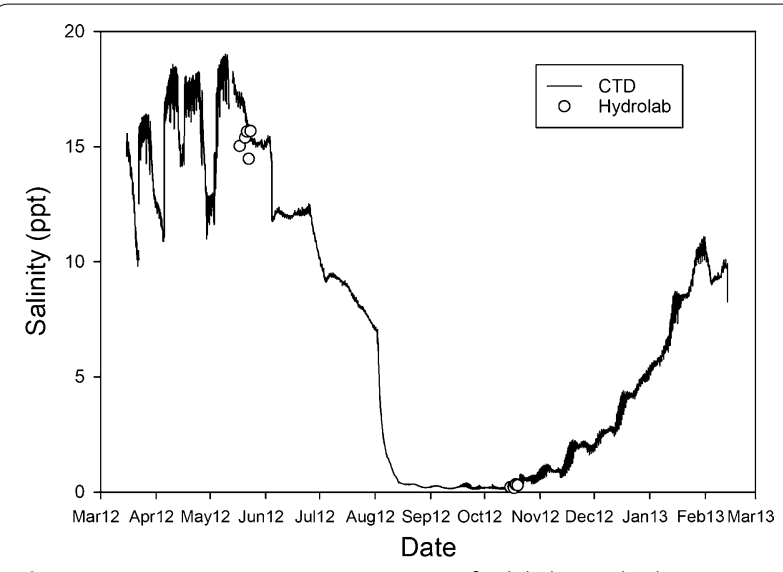

Fig. 4 Continuous CTD measurements of tidal channel salinity over a 1-year period, from March 2012 to February 2013, show salinity variation throughout the wet and dry seasons. Discrete measurements made using the Hydrolab in May and October 2013 are shown by open black circles

Kolmogorov-Smirnov tests. All statistical tests and plots therefore use $\log _{10}$ values of concentrations. Parametric statistical tests were used unless their assumptions were violated (e.g., non-normal distributions), in which case equivalent nonparametric tests were used. Cutoffs for statistical tests are at a significance level $\mathrm{P}=0.05$, meaning that any differences referred to in the following discussion are significant at the $95 \%$ level. Uncertainties in normally distributed parameters are reported as one standard deviation $(1 \sigma)$.

\section{Tidal channels}

The continuous measurements of tidal channel salinity from the CTD (location in Fig. 1) were compared with discrete measurements made using a Hydrolab in May and October 2013 (various locations shown in Fig. 1). The two different methods show good agreement $\left(\mathrm{r}^{2}=0.99\right)$, with an average difference of $8 \%$ between measurements made at the same times likely caused by spatial variability (Fig. 4). Salinity measurements show that the tidal channels surrounding Polder 32 were brackish at the beginning of the deployment period (March to May), during the winter dry season in southwest Bangladesh. While there was much heterogeneity from March to May, the salinity in the tidal channels was on average $15 \mathrm{ppt}$, exhibiting slightly higher salinity, $17-19 \mathrm{ppt}$, during spring tides and slightly lower salinity, 10-13 ppt, during neap tides. During the wet monsoon season (late May to August), surface waters gradually freshened in this region, reaching salinities as low as $0.15 \mathrm{ppt}$ and remaining low until October.

Because tidal channel samples have much higher salinities in May than in October, water samples were divided 
Fig. 5 Box and whisker plots of water compositions classified by water type. "TC" indicates tidal channel. In all plots the horizontal line inside the box represents the median. The boxes'lower boundary is the 25th percentile and upper boundary the 75th percentile. The sample mean is an " $x$ " symbol. The "whiskers" extend to 1.5 times the interquartile range above and below the box, and outliers that plot outside the interquartile range are shown as circles. Tubewell groundwater sample data from [12]. a Specific conductivity in $\mathrm{mS} / \mathrm{cm}$ measured in the field using a Hydrolab. For reference, the conductivity of pure seawater is $\sim 50 \mathrm{mS} / \mathrm{cm}$. The Bangladesh government drinking water guideline of $2 \mathrm{mS} / \mathrm{cm}$ is shown as a horizontal red line. b $\log _{10}$ values of arsenic concentrations in $\mathrm{mg} / \mathrm{L}$. The solid red line corresponds to the Bangladesh government drinking water guideline of $50 \mu \mathrm{g} / \mathrm{L}$, and the dashed red line indicates the WHO guideline of $10 \mathrm{\mu g} / \mathrm{L}$. Arsenic in rainwater was below detection. $\mathbf{c} \log _{10}$ values of sulfur concentrations in $\mathrm{mg} / \mathrm{L}$. $\mathbf{d} \log _{10}$ values of dissolved organic carbon concentrations in $\mathrm{mg} / \mathrm{L}$. e $\mathrm{Cl} / \mathrm{Br}$ mass ratio. The solid red line corresponds to seawater

into "tidal channel May" and "tidal channel October" groups. Four samples collected in October 2013 from irrigation channels that connect rice paddies to the tidal channels (samples SW-105, TC-09, TC-10, and TC-11) were not significantly different from October tidal channel samples, consistent with observations that the irrigation channels were hydraulically connected to the tidal channels. These samples were therefore classified as tidal channel October samples in the analyses (Table 2).

\section{Freshwater ponds}

Besides tidal channels, the only other surface water type for which we have multiple samples in both May and October is freshwater pond. Freshwater pond samples in May have significantly higher $\mathrm{SpC}, \mathrm{As}, \mathrm{Na}, \mathrm{S}$, and DOC than in October, but no significant differences are observed for $\mathrm{pH}$ or $\mathrm{P}$ (Table 2). However, even significant differences are small. For example, average salinity was 1.3 ppt in May and 0.8 ppt in October (Table 3). Furthermore, histograms and normality tests suggest that all freshwater pond samples can be treated as a single population, which we do for simplicity.

\section{Comparison of water types}

Freshwater pond and rice paddy samples are all found to be $\mathrm{Na}-\mathrm{Cl}$ water type and oversaturated in dolomite and calcite. All shrimp pond samples are $\mathrm{Na}-\mathrm{Cl}$ type and oversaturated in dolomite and calcite. One tidal channel sample is $\mathrm{Na}-\mathrm{HCO}_{3}$ type while all others are $\mathrm{Na}-\mathrm{Cl}$ type. All tidal channel samples are saturated in goethite, calcite, and dolomite.

Using $\mathrm{SpC}$ as a measure of salinity, we observe three general salinity groupings for surface water (Fig. 5a). Shrimp pond and May tidal channel samples have very

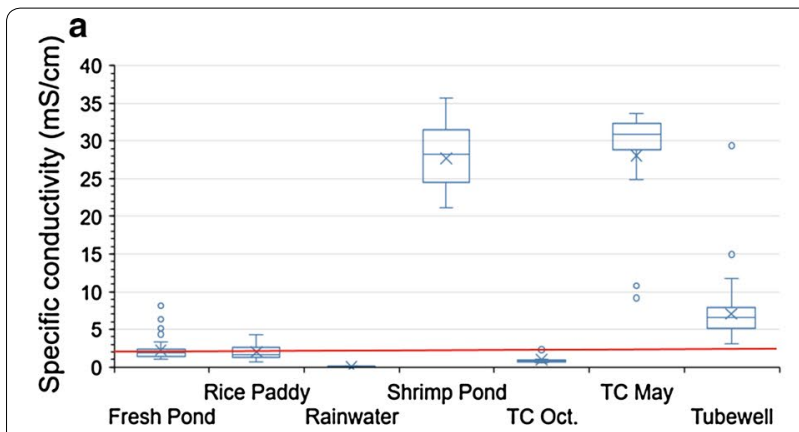

b

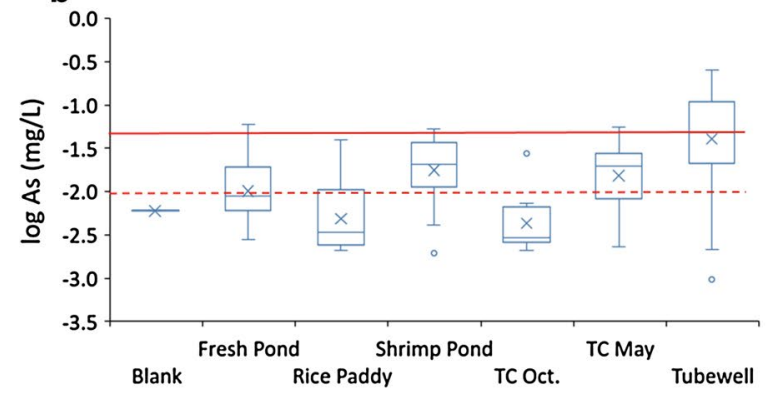

C

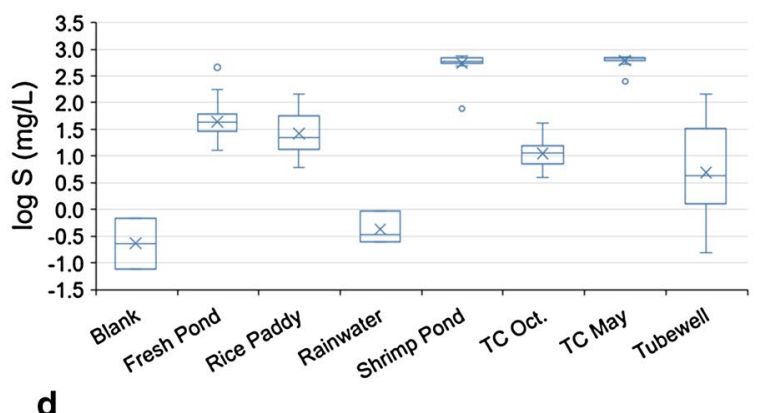

d

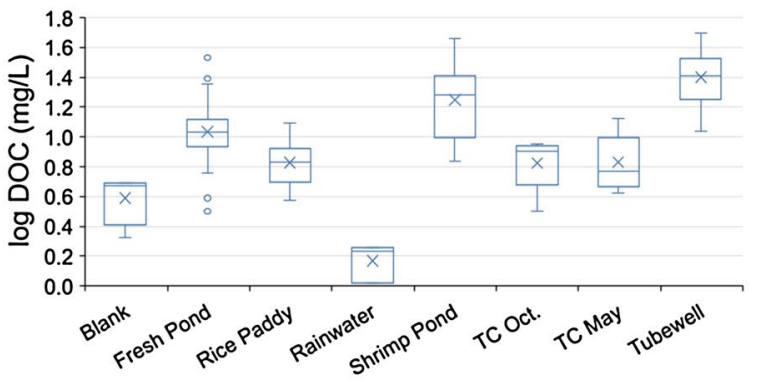

e

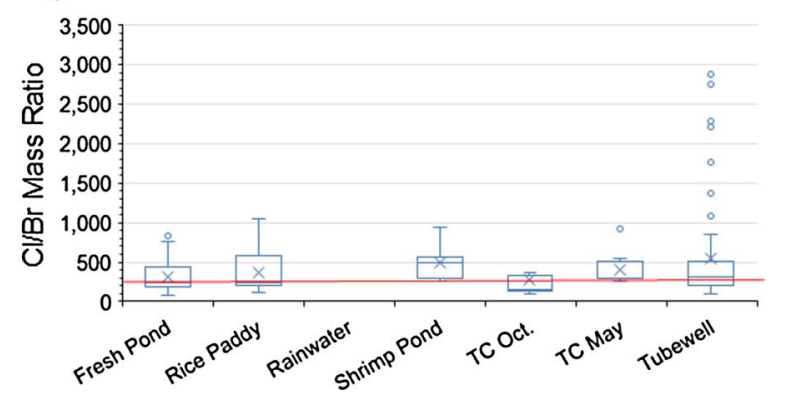




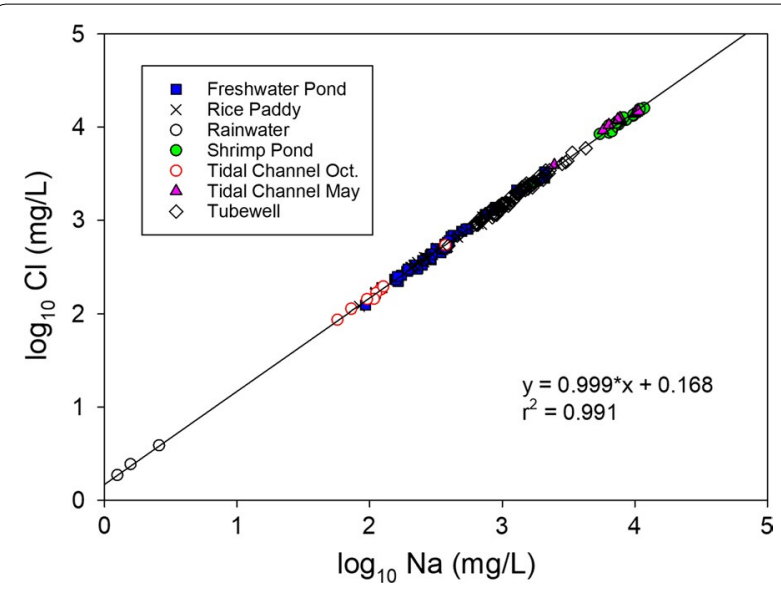

Fig. 6 Scatter plot illustrating the correlation between $\log _{10}$ concentrations of conservative elements $\mathrm{Na}$ and $\mathrm{Cl}$. Samples classified by water type

high and similar conductivities $\sim 1 / 2$ to $2 / 3$ that of pure seawater $(\sim 30 \mathrm{mS} / \mathrm{cm}$, pure seawater is $50 \mathrm{mS} / \mathrm{cm}=35$ ppt). Tubewell samples have intermediate conductivities $(\sim 5-10 \mathrm{mS} / \mathrm{cm}$; all tubewell groundwater compositional data from [12]. All other surface water types have low conductivities $(\sim 1-3 \mathrm{mS} / \mathrm{cm})$. In general, surface waters on and around Polder 32 have lower salinity in the wet season than in the dry season.

Concentrations of $\mathrm{Na}$ and $\mathrm{Cl}$ are positively correlated, and all water types plot on the same linear trend, indicating that these elements behave conservatively (Fig. 6). Dry season tidal channel and shrimp pond water samples have the highest concentrations and rainwater has the lowest concentrations of $\mathrm{Na}$ and $\mathrm{Cl}$. Although they do not show perfect correlations, concentrations of B, K, S, $\mathrm{Mg}$ and $\mathrm{Sr}$ are well correlated with concentrations of $\mathrm{Na}$ and $\mathrm{Cl}$, suggesting they also can be treated as conservative elements (Table 4, Additional file 1: Fig. S1). While $\mathrm{S}$ does not behave conservatively in TW samples [12], it does in all surface water samples because it occurs as sulfate ion under oxidizing conditions.

In contrast, redox-sensitive species such as As, Fe, and DOC do not behave conservatively (Additional file 2: Fig. S2). Tubewell groundwater As concentrations are significantly higher and show greater variability than all other water types (Fig. 5b; Table 3). Dry season tidal channel water and shrimp pond water have intermediate As concentrations, followed by freshwater ponds, and then rice paddies and wet season tidal channel samples with the lowest As concentrations.

Sulfur shows very large differences in concentrations between water types (Fig. 5c). Sulfur concentrations in shrimp pond and dry season tidal channel water samples have very similar and by far the highest concentrations of all water types. Besides rainwater and blanks, groundwater samples from tubewells have the lowest sulfur concentrations.

The geometric mean DOC concentration in both May and October tidal channels of $\sim 6.7 \mathrm{mg} / \mathrm{L}$ (Table 3) is almost identical to the world average for rivers of $5.8 \mathrm{mg} / \mathrm{L}$ [38], while the $18 \mathrm{mg} / \mathrm{L}$ in shrimp ponds and $11 \mathrm{mg} / \mathrm{L}$ in freshwater ponds are similar to the $12 \mathrm{mg} / \mathrm{L}$ world median in eutrophic lakes [39] (Fig. 5d). Groundwater samples have the highest geometric mean DOC concentration of $25 \mathrm{mg} / \mathrm{L}$ (Fig. 5d), much higher than the global groundwater median of $0.7 \mathrm{mg} / \mathrm{L}$ [39]. No correlations are observed between Eh, concentrations of

Table 4 Pearson correlation coefficient matrix for all surface water and groundwater samples

\begin{tabular}{|c|c|c|c|c|c|c|c|c|c|c|c|c|c|c|}
\hline & Eh & $\mathrm{H}^{+}$ & As & B & $\mathrm{Ca}$ & $\mathrm{Fe}$ & $\mathrm{K}$ & $\mathrm{Mg}$ & $\mathrm{Na}$ & $S$ & $\mathrm{Sr}$ & $\mathrm{Cl}$ & $\mathrm{HCO}_{3}{ }^{-}$ & DOC \\
\hline Eh & 1 & & & & & & & & & & & & & \\
\hline $\mathrm{H}^{+}$ & -0.41 & 1 & & & & & & & & & & & & \\
\hline As & -0.39 & 0.34 & 1 & & & & & & & & & & & \\
\hline B & 0.09 & -0.06 & -0.04 & 1 & & & & & & & & & & \\
\hline $\mathrm{Ca}$ & -0.13 & 0.34 & 0.15 & 0.53 & 1 & & & & & & & & & \\
\hline $\mathrm{Fe}$ & -0.38 & 0.27 & 0.18 & -0.13 & 0.35 & 1 & & & & & & & & \\
\hline K & 0.38 & -0.12 & -0.13 & 0.91 & 0.55 & -0.17 & 1 & & & & & & & \\
\hline $\mathrm{Mg}$ & 0.22 & -0.02 & -0.08 & 0.94 & 0.70 & -0.04 & 0.96 & 1 & & & & & & \\
\hline $\mathrm{Na}$ & 0.31 & -0.05 & -0.09 & 0.91 & 0.64 & -0.11 & 0.97 & 0.96 & 1 & & & & & \\
\hline$S$ & 0.39 & -0.23 & -0.19 & 0.89 & 0.52 & -0.22 & 0.96 & 0.92 & 0.92 & 1 & & & & \\
\hline $\mathrm{Sr}$ & 0.07 & 0.05 & 0.01 & 0.91 & 0.77 & -0.02 & 0.88 & 0.96 & 0.92 & 0.85 & 1 & & & \\
\hline $\mathrm{Cl}$ & 0.28 & -0.05 & -0.09 & 0.93 & 0.64 & -0.11 & 0.97 & 0.98 & 1.00 & 0.92 & 0.94 & 1 & & \\
\hline $\mathrm{HCO}_{3}^{-}$ & -0.69 & 0.38 & 0.59 & 0.03 & 0.22 & 0.35 & -0.18 & -0.09 & -0.09 & -0.29 & 0.02 & -0.10 & 1 & \\
\hline DOC & -0.28 & 0.15 & 0.52 & 0.01 & 0.26 & 0.29 & -0.05 & -0.01 & 0.05 & -0.11 & 0.03 & 0.02 & 0.87 & 1 \\
\hline
\end{tabular}


Table 5 Principal components loadings

\begin{tabular}{lcc}
\hline Factor & $\mathbf{1}$ & $\mathbf{2}$ \\
\hline Eh $(\mathrm{mV})$ & -0.012 & -0.212 \\
$\mathrm{pH}$ & -0.061 & -0.187 \\
$\log \mathrm{As}(\mu \mathrm{g} / \mathrm{L})$ & 0.055 & 0.179 \\
$\log B(\mu \mathrm{g} / \mathrm{L})$ & 0.132 & -0.005 \\
$\log \mathrm{Ca}(\mu \mathrm{g} / \mathrm{L})$ & 0.13 & 0.011 \\
$\log \mathrm{Fe}(\mu \mathrm{g} / \mathrm{L})$ & 0.038 & 0.239 \\
$\log \mathrm{K}(\mu \mathrm{g} / \mathrm{L})$ & 0.13 & -0.105 \\
$\log \mathrm{Mg}(\mu \mathrm{g} / \mathrm{L})$ & 0.144 & -0.044 \\
$\log \mathrm{Na}(\mu \mathrm{g} / \mathrm{L})$ & 0.144 & -0.033 \\
$\log \mathrm{S}(\mu \mathrm{g} / \mathrm{L})$ & 0.048 & -0.228 \\
$\log \mathrm{Sr}(\mu \mathrm{g} / \mathrm{L})$ & 0.144 & -0.02 \\
$\log \mathrm{Cl}(\mu \mathrm{g} / \mathrm{L})$ & 0.144 & -0.031 \\
$\log \mathrm{DOC}(\mu \mathrm{g} / \mathrm{L})$ & 0.048 & 0.193 \\
\hline
\end{tabular}

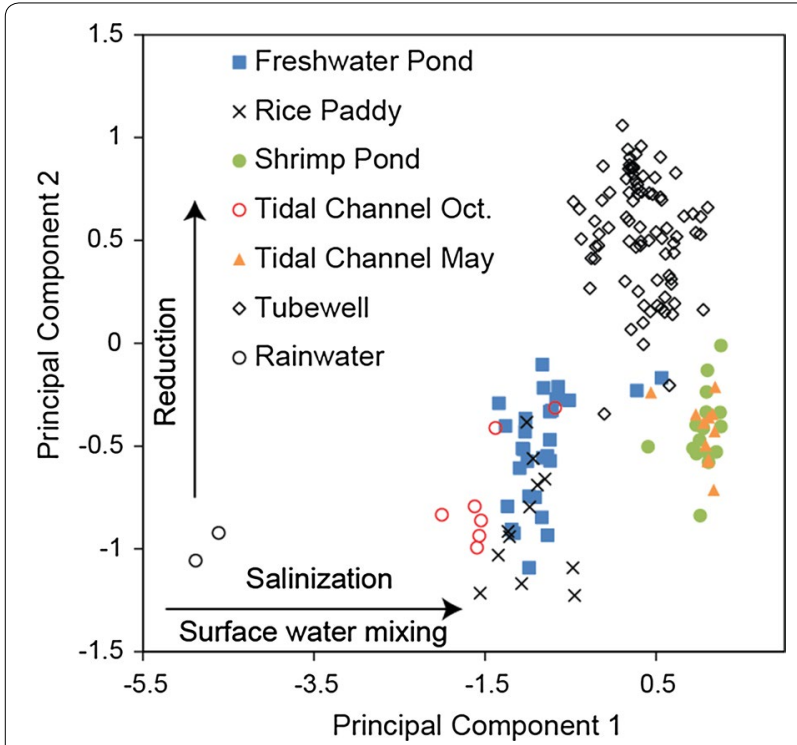

Fig. 7 Plot of principal component scores of water samples classified by water type

reducing agents (DOC), and concentrations of elements with variable oxidation states (As, Fe, $\mathrm{Mn}, \mathrm{M}$, and S), indicating that redox disequilibrium is the norm.

\section{Principal components analysis}

A principal components analysis showed that only two factors $\mathrm{PC} 1$ and $\mathrm{PC} 2$ are needed to explain $80 \%$ of the compositional variance. For $\mathrm{PC} 1$ the resulting equation is:

$$
\begin{aligned}
\mathrm{PC} 1= & -0.012 \mathrm{z}_{\mathrm{Eh}}-0.061 \mathrm{z}_{\mathrm{pH}}+0.055 \mathrm{z}_{\mathrm{As}}+0.132 \mathrm{z}_{\mathrm{B}} \\
& +0.13 \mathrm{z}_{\mathrm{Ca}}+0.038 \mathrm{z}_{\mathrm{Fe}}+0.13 \mathrm{z}_{\mathrm{K}}+0.144 \mathrm{z}_{\mathrm{Mg}} \\
& +0.144 \mathrm{z}_{\mathrm{Na}}+0.048 \mathrm{z}_{\mathrm{S}}+0.144 \mathrm{z}_{\mathrm{Sr}}+0.144 \mathrm{z}_{\mathrm{Cl}} \\
& +0.048 \mathrm{z}_{\mathrm{DOC}}
\end{aligned}
$$

where " $\mathrm{z}$ " is the $\mathrm{z}$-score for each compositional variable. PC2 is calculated in an analogous fashion using the coefficients for factor 2 in Table 5. PC1 is plotted versus PC2 in Fig. 7.

\section{Discussion \\ Salinization \\ Tidal channels and shrimp ponds}

Tidal channel water shows the greatest seasonal variation in composition of all water types, having much lower salinity during the monsoon due to dilution from freshwater sources (Figs. 4, 5a, 6). These variations in tidal channel salinity are due to variable degrees of mixing of Bay of Bengal seawater with the freshwater plume of the Ganges-Brahmaputra River, which mix on the shelf and are advected inland with the tides [40]. Wet-season runoff and discharge from the Gorai River also contribute to seasonal variability in tidal channel salinity. In contrast, compositions of dry season tidal channel and shrimp pond water are nearly indistinguishable (Fig. 5), even for nutrients such as phosphorus that are added to shrimp ponds as fertilizer (Table 2). For example, their very high and similar sulfur concentrations suggest that shrimp pond water is sourced from dry season tidal channels rather than tubewells, and that seawater sulfate is present under oxidizing conditions. Only DOC (Fig. 5d) and Mn show significantly different concentrations between dry season tidal channel and shrimp pond samples, and those differences can be attributed to nonconservative behavior (redox cycling or sorption).

The Bangladesh government guideline for the salinity of drinking water of $2 \mathrm{mS} / \mathrm{cm} \mathrm{[1]}$ is exceeded by $11 \%$ of wet season tidal channel samples and $100 \%$ of shrimp pond and dry season tidal channel samples (Table 3). Shrimp ponds are present only in the dry season, and are always close to tidal channels. Their similar compositions and spatial and temporal proximities confirm that dry season tidal channels provide the water and dissolved salts in brine shrimp ponds (Fig. 5). Observations of sluice gates in embankments separating shrimp ponds from tidal channels and discussions with shrimp farmers confirmed this inference. At low tide shrimp ponds can be drained into the tidal channel, and at high tide tidal channel water can be added to the shrimp ponds. Since the only surface water types that are highly saline are May tidal channel and shrimp pond, and May tidal channel water is the source of salts in shrimp ponds, it is the most likely source of salts in all surface water types except rainwater (exhibited by the mixing curve in Fig. 6).

Just as they are not the ultimate source of salts in surface waters, shrimp ponds are unlikely to be the source of salts in groundwater. Much evidence supports this notion, including lack of a correlation between 
groundwater salinity and distance to nearest shrimp pond [12]. Like the rest of the polder, shrimp ponds are underlain by impermeable muds that cap the surface stratigraphy in this region, limiting or preventing surface recharge [12]. Furthermore, old ${ }^{14} \mathrm{C}$ ages and low tritium contents in groundwater from the shallow aquifer beneath Polder 32 confirm that there is limited surface recharge that would allow shrimp ponds to contaminate the shallow aquifer [13]. Thus, the source of salts in the groundwater is connate tidal channel water from deposition of aquifer sands during the mid-late Holocene [12].

Surface muds also prevent movement of saline shrimp pond water into adjacent freshwater ponds. For example, on polder 31 in May 2012 the specific conductivity of freshwater pond SW-08 was $1.4 \mathrm{mS} / \mathrm{cm}$, while $10 \mathrm{~m}$ away the specific conductivity of brine shrimp pond SW-09 was $28 \mathrm{mS} / \mathrm{cm}$ (Fig. 1). This observation that freshwater could be maintained in a pond adjacent to a saline shrimp pond suggests that surface deposits are impermeable enough (i.e., have a low enough hydraulic conductivity) to prevent the transfer of salts through meter-scale pond embankments.

\section{Rice paddies}

Rice paddies are inundated with surface water only in the wet season. Field observations and analysis of satellite imagery show that rice paddy water comes from irrigation channels sourced from inland streams connected to tidal channels (Figs. 1, 2, 3). DOC contents of water from rice paddies and tidal channels support this inference, as they are similar to each other but different from all other water types present in the wet season (Fig. 5d). However, the median specific conductivity is significantly higher for rice paddy water than for wet season tidal channel water (Fig. 5a). This can be explained by three different scenarios, as explained below.

One explanation for the salinity of rice paddy water being higher than in the wet season tidal channel water is that it is sourced from salts deposited in the soil during the 2 years of tidal inundation following the embankment failures during Cyclone Aila in 2009 [20]. These salts would have slowly leached into soil porewater, and then diffused into the overlying paddy water during subsequent rice cultivation seasons. If this happened, we would expect the salinity of rice paddy water to be higher in areas that were inundated than in those that were not, but there is no statistically significant difference in specific conductivity (sites that were inundated are listed in Table 1).

Similarly, the higher conductivity of rice paddy water may result from the land being used for brine shrimp aquaculture in the dry season. A previous 15-year study showed that alternating shrimp farming with rice farming caused increases in soil salinity and decreases in rice yield [11]. However, our data show no significant difference in rice paddy water conductivity between samples from rice paddies that were shrimp ponds (Table 2, locations classified as rice paddy in October and shrimp pond in May) and samples from rice paddies that were not. Rice paddy water therefore shows no strong evidence of salinization caused by shrimp farming. Salts in shrimp ponds are mostly removed by discharging shrimp pond effluents to tidal channels, preventing salinization of agricultural fields. Any remaining salts in the soil are likely flushed out during wet season irrigation of rice paddies, preventing salt accumulation. Despite these findings, the potential for soil salinization caused by shrimp farming cannot be excluded for all areas due to variation in local water sources and farming methods.

Finally, the higher conductivity of rice paddy water may result from evaporation. The geometric mean concentrations of conservative elements are uniformly $\sim 3 \times$ higher in rice paddy water than in wet season tidal channel water (Fig. 6), suggesting they are concentrated about $3 \times$ by evaporation. Rice paddies are prone to evaporative concentration because they are relatively shallow and subject to more significant temperature variations, compared to their deeper irrigation channel and tidal channel counterparts $(\sim 15-20 \mathrm{~cm}$ versus $\sim 100-500 \mathrm{~cm}$, respectively). Given these lines of evidence, we conclude that evaporation is the main cause of elevated salinity of rice paddy water relative to its wet season tidal channel source.

\section{Freshwater ponds}

Freshwater ponds are filled by rainwater, but may become saline when salts are added during inundation and concentrated by evaporation. Because freshwater ponds are closed depressions with no outlets, the only way that salts can be removed is through water abstraction, which combined with dilution from precipitation would cause the water to gradually become less saline after an inundation event. Freshwater ponds that were in areas inundated following Cyclone Aila in 2009 were not significantly more saline than those that were not in inundated areas (Tables 1,2). This was true in both wet and dry seasons, even in May 2012, only 2 years after inundation ended. Thus, abstraction and dilution erased any evidence of increased salinity in freshwater ponds caused by inundation.

The average molar $\mathrm{Na} / \mathrm{Cl}$ in freshwater ponds is 1.05 , close enough to one to suggest that $\mathrm{Na}$ and $\mathrm{Cl}$ are added as $\mathrm{NaCl}$, most likely in sea spray that returns to the surface during precipitation [41]. The concentrations of $\mathrm{Na}^{+}$ and $\mathrm{Cl}^{-}$in freshwater ponds are $238 \times$ and $235 \times$ higher respectively than in rainwater, which makes evaporative 
concentration alone an unlikely explanation for the salinity of freshwater ponds being so much higher than in rainwater. However, because all water types have the same proportions of $\mathrm{Na}$ and $\mathrm{Cl}$ (Fig. 6), it is difficult to uniquely identify the salinity source in freshwater ponds. The $\mathrm{Cl} / \mathrm{Br}$ mass ratio has been used to distinguish seawater $(=290)$ from other salt sources with higher $\mathrm{Cl} / \mathrm{Br}$ such as urine and West Bengal halite [42], but median and average $\mathrm{Cl} / \mathrm{Br}$ for freshwater ponds are close to seawater (Fig. 5e). Seawater, whether in sea spray or in tidal channel water, is likely the ultimate source of salts in freshwater ponds, although molar $\mathrm{Na} / \mathrm{Cl}$ in seawater is only 0.86 [43].

\section{Arsenic contamination}

Arsenic concentrations are generally higher in groundwater than all surface water types (Fig. 5b), consistent with results from previous work [44]. Of surface water types, concentrations of As are highest in shrimp pond water and dry season tidal channel water it is derived from, but significantly lower in wet season tidal channel water (Table 3). In both dry and wet seasons As concentrations in tidal channel water are higher than the global average river water As concentration of $0.83 \mu \mathrm{g} / \mathrm{L}$ [45]. It is possible that As in tidal channel water is derived from groundwater added to the tidal channel, perhaps by groundwater irrigation of rice paddies upstream, since As concentrations are highest in groundwater. The higher concentration of As in tidal channel water in the dry season may result from a greater proportion of groundwater than in tidal channel water in the wet season when surface runoff and river discharge are high. Higher head gradients in the dry season may also cause greater discharge of reducing As-rich groundwater into tidal channels as baseflow [32].

Arsenic concentration exceeds $10 \mu \mathrm{g} / \mathrm{L}$ in $43 \%$ of freshwater ponds (Table 3). Arsenic may have been leached out of sediments lining the pond, especially if the pond was recently excavated, or it may have been added by tidal channel water during inundation. Deposition of As by groundwater seepage seems unlikely unless the mud cap was breached during pond excavation.

Of the 18 rice paddy water samples collected, 22\% exceeded $10 \mu \mathrm{g} / \mathrm{L}$, and the geometric mean As concentration was $5 \mu \mathrm{g} / \mathrm{L}$ (Table 3). Because rice paddies in Polder 32 are irrigated with tidal channel water and not groundwater, tidal channels are the local source of As. However, groundwater is likely the ultimate source of As, as it has the highest As concentrations. Much of the As added to rice paddies by groundwater or tidal channel water irrigation during the dry season is removed by floodwaters in the wet season [46]. However, poldering has reduced the frequency of inundation with fresh tidal channel water during the wet season, which may be causing As from irrigation water to accumulate in rice paddy soil and water. Still, rice paddy water As concentrations in Polder 32 are lower than in areas where groundwater from the shallow aquifer is used to irrigate rice paddies $[47,48]$.

\section{Compositional relationships between water types}

Figure 6 shows that, for conservative elements, all water types can be formed by mixing of high salinity dry season tidal channel water with rainwater. Salinization of surface water is caused by tidal channel water inundation or irrigation, while the intermediate salt content of shallow groundwater is inherited from tidal channel water trapped in sediments during deposition [12]. Any deviation in composition from a dry season tidal channel water-rainwater mixture is due to nonconservative behavior, which primarily affects ions with multiple valence states. Nonconservative behavior is most apparent in groundwater compositions, which have lower Eh values than surface waters, and have much lower $\mathrm{S}$ concentrations than expected based on the proportions of tidal channel water and rainwater estimated from conservative element concentrations [12].

These observations suggest that only two factors explain most of the observed variation in compositions of all water types: salinization by mixing of saline tidal channel water with freshwater, followed by post-depositional progressive reduction of groundwater. Plotting principal components scores PC1 and PC2 for all samples classified by water type shows that PC1 increases with increasing dissolved salt content and therefore represents the process of salinization (Fig. 7). The conservative elements $\mathrm{B}, \mathrm{Ca}, \mathrm{K}, \mathrm{Mg}, \mathrm{Na}, \mathrm{Sr}$ and $\mathrm{Cl}$ have the highest loadings on $\mathrm{PC} 1$ and are all positively correlated. $\mathrm{PC} 2$ represents progressive reduction, which affects the concentrations of nonconservative elements in groundwater. The PC2 scores for groundwater samples are higher than for surface water samples because groundwaters are more reducing (Fig. 7).

The principal components plot concisely summarizes the compositional relationships between the different water types. Since the PC factor scores are a measure of water composition, water types with similar compositions plot in the same areas. For example, dry season tidal channel water is compositionally similar to shrimp pond samples (Fig. 7), indicating that shrimp farmers draw water from the tidal channels for their shrimp ponds. Since the factor scores are calculated as linear combinations of compositional variables, mixtures plot on linear mixing lines connecting endmembers. Waters in wet season tidal channels, freshwater ponds and rice paddies can form as mixtures of dry season tidal channel water and 
rainwater. Groundwater compositions are distinct from all surface water types and could have formed by mixing of dry season tidal channel water and rainwater followed by reduction. The anomalously high DOC in groundwater is likely preserved from the connate water, as soil porewater in the Sundarbans has similarly high DOC $[12,49]$. The DOC could also derive from surface sources such as freshwater ponds and shrimp ponds [50-52], which have high measured DOC concentrations (Fig. 5d).

The relationships between the concentrations of redoxsensitive species can be explained by examining their associated redox reactions. For iron:

$\mathrm{FeO}(\mathrm{OH})+2 \mathrm{H}^{+}+=1.5 \mathrm{H}_{2} \mathrm{O}+0.25 \mathrm{O}_{2}(\mathrm{aq})+\mathrm{Fe}^{2+}$

For sulfur:

$$
2 \mathrm{H}^{+}+\mathrm{SO}_{4}^{2-}=\mathrm{H}_{2} \mathrm{~S}(\mathrm{aq})+2 \mathrm{O}_{2}(\mathrm{aq})
$$

For carbon, where reduced organic matter is indicated by methane $\mathrm{CH}_{4}$ :

$$
8 \mathrm{CH}_{4}(\mathrm{aq})+16 \mathrm{O}_{2}(\mathrm{aq})=8 \mathrm{HCO}_{3}^{-}+8 \mathrm{H}_{2} \mathrm{O}+8 \mathrm{H}^{+}
$$

For arsenic, where the dominant forms of reduced $\left(\mathrm{As}(\mathrm{OH})_{3} \mathrm{aq}\right)$ and oxidized $\left(\mathrm{HAsO}_{4}{ }^{2-}\right)$ arsenic correspond to the observed $\mathrm{pH}$ values of most surface waters:

$$
2 \mathrm{H}^{+}+\mathrm{HAsO}_{4}^{2-}=\mathrm{As}(\mathrm{OH})_{3}(\mathrm{aq})+0.5 \mathrm{O}_{2}(\mathrm{aq})
$$

Combining Eqs. (3)-(6) and indicating $\mathrm{HAsO}_{4}{ }^{2-}$ as being sorbed to goethite $\mathrm{FeO}(\mathrm{OH})$ so that it is immobile:

$$
\begin{aligned}
\mathrm{FeO}(\mathrm{OH})> & \mathrm{HAsO}_{4}^{2-}+\mathrm{SO}_{4}^{2-}+8 \mathrm{CH}_{4}(\mathrm{aq})+13.25 \mathrm{O}_{2}(\mathrm{aq}) \\
= & \mathrm{H}_{2} \mathrm{~S}+\mathrm{Fe}^{2+}+9.5 \mathrm{H}_{2} \mathrm{O}+2 \mathrm{H}^{+} \\
& +8 \mathrm{HCO}_{3}^{-}+\mathrm{As}(\mathrm{OH})_{3}(\mathrm{aq})
\end{aligned}
$$

Our geochemical interpretation is that reaction of DOC (represented simply as $\mathrm{CH}_{4}$ ) drives the reaction to the right, causing progressive reduction, reductive dissolution of ferric oxyhydroxide $\mathrm{FeO}(\mathrm{OH})$, and release of sorbed As, resulting in increased groundwater concentrations of dissolved As and Fe. At low Eh values $\mathrm{H}_{2} \mathrm{~S}$ escapes or sulfides precipitate, decreasing aqueous $\mathrm{S}$ concentrations [12].

A correlation analysis for all surface water and groundwater samples is consistent with the compositional trends predicted by Eq. (7). In Table 4 in the row labeled "DOC" the signs of the Pearson correlation coefficient $r$ values correspond to the signs of the stoichiometric coefficients in Eq. (7). As DOC is consumed as a reactant during progressive reduction, Eh and $\mathrm{S}$ decrease (negative coefficients), and $\mathrm{Fe}, \mathrm{As}, \mathrm{H}^{+}$, and $\mathrm{HCO}_{3}{ }^{-}$increase (positive coefficients). Also, pairs of conservative elements have correlation coefficient values close to 1 (Table 4).

\section{Conclusions}

In the area of Polder 32 in southwest Bangladesh drinking water sources include groundwater from the shallow aquifer and surface freshwater ponds. Groundwater is moderately saline (median salinity of $3.6 \mathrm{ppt}$ ). Freshwater ponds have lower salinity (1.1 ppt). All sampled surface waters are mixtures of tidal channel water and rainwater.

In the wet season rice paddy water is obtained from tidal channels via sluice gates along former stream channels and irrigation channels, but the low level of salts becomes concentrated $\sim 3 \times$ by evaporation. In the dry season shrimp are farmed using saline tidal channel water. Alternating rice and shrimp farming in this area appears to have a negligible effect on rice paddy water composition and presumably on rice yields. Thus, in the area studied brine shrimp aquaculture can be sustainable if effectively managed. However, the WHO guideline of $10 \mu \mathrm{g} / \mathrm{L}$ As is exceeded by $83 \%$ of groundwater, $78 \%$ of shrimp pond, $71 \%$ of May tidal channel, $41 \%$ of freshwater pond, $22 \%$ of rice paddy, and $11 \%$ of October tidal channel samples. The high percentage of water samples that exceed the WHO guideline raises concerns about the arsenic content of shrimp grown in shrimp ponds, rice grown in rice paddies, and drinking water obtained from tubewells and freshwater ponds.

\section{Additional files}

Additional file 1: Figure S1. Stacked histograms and bivariate scatter plots of concentrations of conservative elements.

Additional file 2: Figure S2. Stacked histograms and bivariate scatter plots of concentrations of non-conservative elements and the water quality parameter Eh, the oxidation-reduction potential.

\section{Authors' contributions}

JCA designed the study, collected water samples in May 2012, provided oversight of chemical analyses, and was primary author of most sections of the manuscript. GG and LB made measurements and collected samples in 2012. LB also helped develop analytical protocols. DF made measurements and collected samples in 2013. CW and LA deployed the CTD, processed the measurements, and wrote the results. KR participated in planning and field campaigns. MRK and FA made measurements and collected samples on all four campaigns. MRK also helped choose sampling locations. All authors read and approved the final manuscript.

\section{Author details}

${ }^{1}$ Department of Earth \& Environmental Sciences, Vanderbilt University, Nashville, TN 37240, USA. ${ }^{2}$ Department of Geology and Geophysics, Louisiana State University, Baton Rouge, LA 70803, USA. ${ }^{3}$ Environmental Science Discipline, Khulna University, Khulna 9208, Bangladesh. ${ }^{4}$ Department of Earth \& Environmental Sciences, Vanderbilt University, PMB 351805, 2301 Vanderbilt Place, Nashville, TN 37235-1805, USA.

\section{Acknowledgements}

Thanks to Rossane DeLapp for analyzing the water samples, David Furbish for advice on geostatistics, and George Hornberger and Jonathan Gilligan for general advice. 


\section{Competing interests}

The authors declare that they have no competing interests.

\section{Availability of data and materials}

The datasets supporting the conclusions of this article are available in the Pangaea repository, https://doi.pangaea.de/10.1594/PANGAEA.875120.

\section{Consent for publication}

All authors have consented to publication.

\section{Ethics approval and consent to participate} Not applicable.

\section{Funding}

This research was supported by grants from the Office of Naval Research \#N00014-11-1-0683 and National Science Foundation OCE-1600319. Any opinions, findings, conclusions, or recommendations expressed in this material are those of the authors and do not necessarily reflect the views of the National Science Foundation.

\section{Publisher's Note}

Springer Nature remains neutral with regard to jurisdictional claims in published maps and institutional affiliations.

Received: 22 May 2017 Accepted: 1 September 2017

Published online: 11 September 2017

\section{References}

1. Benneyworth L, Gilligan J, Ayers J et al (2016) Drinking water insecurity: water quality and access in coastal south-western Bangladesh. Int J Environ Health Res. doi:10.1080/09603123.2016.1194383

2. World Health Organization (2011) Guidelines for drinking-water quality, 4th edn. WHO, Geneva

3. British Geological Survey, Bangladesh Department of Public Health and Engineering (2001) Arsenic contamination of groundwater in Bangladesh

4. Hopenhayn C (2006) Arsenic in drinking water: impact on human health. Elements 2:103-107. doi:10.2113/gselements.2.2.103

5. Mitchell VL (2014) Health risks associated with chronic exposures to arsenic in the environment. Rev Min Geochem 79:435-449. doi:10.2138/ rmg.2014.79.8

6. Williams PN, Islam MR, Adomako EE et al (2006) Increase in rice grain arsenic for regions of Bangladesh irrigating paddies with elevated arsenic in groundwaters. Environ Sci Technol 40:4903-4908. doi:10.1021/es060222i

7. Khan MA, Stroud JL, Zhu Y-G et al (2010) Arsenic bioavailability to rice is elevated in Bangladeshi paddy soils. Environ Sci Technol 44:8515-8521. doi:10.1021/es101952f

8. Clarke D, Williams S, Jahiruddin M et al (2015) Projections of on-farm salinity in coastal Bangladesh. Environ Sci Process Impacts 17:1127-1136. doi:10.1039/C4EM00682H

9. Environmental Protection Agency (2003) Drinking water advisory: consumer acceptability advice and health effects analysis

10. Khan A, Ireson A, Kovats S (2011) Drinking water salinity and maternal health in coastal Bangladesh: implications of climate change. Environ Health Perspect 119:1328-1332

11. Ali AMS (2006) Rice to shrimp: land use/land cover changes and soil degradation in southwestern Bangladesh. Land Use Policy 23:421-435. doi:10.1016/j.landusepol.2005.02.001

12. Ayers JC, Goodbred S, George G et al (2016) Sources of salinity and arsenic in groundwater in southwest Bangladesh. Geochem Trans 17:1-22. doi:10.1186/s12932-016-0036-6

13. Worland SC, Hornberger GM, Goodbred SL (2015) Source, transport, and evolution of saline groundwater in a shallow Holocene aquifer on the tidal deltaplain of southwest Bangladesh. Water Resour Res 51:57915805. doi:10.1002/2015WR017198.A

14. Allison M, Khan S, Goodbred S, Kuehl S (2003) Stratigraphic evolution of the late Holocene Ganges-Brahmaputra lower delta plain. Sediment Geol 155:317-342
15. Goodbred SL, Paolo PM, Ullah MS et al (2014) Piecing together the Ganges-Brahmaputra-Meghna River delta: use of sediment provenance to reconstruct the history and interaction of multiple fluvial systems during Holocene delta evolution. Geol Soc Am Bull 126:1495-1510. doi:10.1130/ B30965.1

16. Mirza M (1998) RESEARCH: diversion of the Ganges water at Farakka and its effects on salinity in Bangladesh. Environ Manag 22:711-722

17. Rogers KG, Goodbred SL, Mondal DR (2013) Monsoon sedimentation on the "abandoned" tide-influenced Ganges-Brahmaputra Delta plain. Estuar Coast Shelf Sci 131:297-309

18. Wilson CA, Goodbred SL (2015) Construction and maintenance of the Ganges-Brahmaputra-Meghna delta: linking process, morphology, and stratigraphy. Annu Rev Mar Sci 7:67-88. doi:10.1146/ annurev-marine-010213-135032

19. Chowdhury N (2010) Water management in Bangladesh: an analytical review. Water Policy 12:32-51

20. Auerbach LW, Goodbred SL Jr, Mondal DR et al (2015) Flood risk of natural and embanked landscapes on the Ganges-Brahmaputra tidal delta plain. Nat Clim Change 5:153-157. doi:10.1038/nclimate2472

21. Pethick J, Orford JD (2013) Rapid rise in effective sea-level in southwest Bangladesh: its causes and contemporary rates. Glob Planet Change 111:237-245. doi:10.1016/j.gloplacha.2013.09.019

22. Wilson CA, Goodbred S, Small C, et al Widespread infilling of tidal channels and navigable waterways in human-modified tidal deltaplain of southwest Bangladesh. Elementa (submitted)

23. Winterwerp JC, Giardino A (2012) Assessment of increasing freshwater input on salinity and sedimentation in the Gorai river system. World Bank Project 1206292-000, Deltares

24. Mehedi H, Nag AK, Farhana S (2010) Climate induced displacementcase study of Cyclone Aila in the southwest coastal region of Bangladesh. Khulna, Bangladesh

25. Dasgupta S, Kamal FA, Khan ZH, et al (2014) River salinity and climate change: evidence from coastal Bangladesh. Dhaka, Bangladesh

26. Azad AK, Jensen KR, Lin CK (2009) Coastal aquaculture development in Bangladesh: unsustainable and sustainable experiences. Environ Manag 44:800-809. doi:10.1007/s00267-009-9356-y

27. Chowdhury M, Khairun Y, Salequzzaman M, Rahman M (2011) Effect of combined shrimp and rice farming on water and soil quality in Bangladesh. Aquac Int 19:1193-1206. doi:10.1007/s10499-011-9433-0

28. Ayers JC, Goodbred S (2017) Arsenic contamination in south and southeast Asia. In: Oxford Bibliogr Environ Sci

29. Baig JA, Kazi TG, Shah AQ et al (2010) Speciation and evaluation of Arsenic in surface water and groundwater samples: a multivariate case study. Ecotoxicol Environ Saf 73:914-923. doi:10.1016/j.ecoenv.2010.01.002

30. Acharyya SK, Chakraborty P, Lahiri S et al (1999) Arsenic poisoning in the Ganges delta. Nature 401:545

31. Fendorf S, Michael HA, van Geen A (2010) Spatial and temporal variations of groundwater arsenic in south and southeast Asia. Science 328:11231127. doi:10.1126/science 1172974

32. Datta S, Mailloux B, Jung H-B et al (2009) Redox trapping of arsenic during groundwater discharge in sediments from the Meghna riverbank in Bangladesh. Proc Natl Acad Sci USA 106:16930-16935. doi:10.1073/ pnas.0908168106

33. Mukherjee A, Fryar AE (2008) Deeper groundwater chemistry and geochemical modeling of the arsenic affected western Bengal basin, West Bengal, India. Appl Geochem 23:863-894

34. Nordstrom DK, Munoz JL (1994) Geochemical thermodynamics, 2nd edn. Blackwell Scientific Publications, Hoboken

35. Rice EW, Baird RB, Eaton AD, Clesceri LS (2012) Standard methods for the examination of water and wastewater. American Public Health Association, American Water Works Association, Water Environment Federation, Washington

36. Bethke CM (2007) Geochemical and biogeochemical reaction modeling. Cambridge University Press, Cambridge

37. Drever Jl (1997) The geochemistry of natural waters : surface and ground water environments, 3rd edn. Prentice Hall, Upper Saddle River

38. Meybeck M (1982) Carbon, nitrogen, and phosphorus transport by world rivers. Am J Sci 282:401-450

39. Perdue EM, Ritchie JD (2003) Dissolved organic matter in freshwaters. In: Turekian KK, Holland HD (eds) Treatise geochemistry, vol 5, Surf. Gr. Water, Weather. Soils. Elsevier, Amsterdam, pp 273-318 
40. Shetye SR, Gouveia AD, Shankar D et al (1996) Hydrography and circulation in the western Bay of Bengal during the northeast monsoon. J Geophys Res Ocean 101:14011-14025

41. Langmuir D (1997) Aqueous environmental geochemistry. Prentice Hall, Upper Saddle River

42. McArthur JM, Sikdar PK, Hoque MA, Ghosal U (2012) Waste-water impacts on groundwater: $\mathrm{Cl} / \mathrm{Br}$ ratios and implications for arsenic pollution of groundwater in the Bengal Basin and Red River Basin, Vietnam. Sci Total Environ 437:390-402. doi:10.1016/j.scitotenv.2012.07.068

43. Taylor SR, McLennan SM (1985) The continental crust: its composition and evolution. Blackwell, Oxford

44. Islam MR, Salminen R, Lahermo PW (2000) Arsenic and other toxic elemental contamination of groundwater, surface water and soil in Bangladesh and its possible effects on human health. Environ Geochem Health 22:33-53. doi:10.1023/A:1006787405626

45. Vaughan DJ (2006) Arsenic. Elements 2:71-75. doi:10.2113/ gselements.2.2.71

46. Roberts LC, Hug SJ, Dittmar J et al (2010) Arsenic release from paddy soils during monsoon flooding. Nat Geosci 3:53-59. doi:10.1038/ngeo723

47. Faroog SH, Chandrasekharam D, Berner $Z$ et al (2010) Influence of traditional agricultural practices on mobilization of arsenic from sediments to groundwater in Bengal delta. Water Res 44:5575-5588. doi:10.1016/j. watres.2010.05.057
48. Roberts LC, Hug SJ, Dittmar J et al (2007) Spatial distribution and temporal variability of arsenic in irrigated rice fields in Bangladesh. 1. Irrigation water. Environ Sci Technol 41:5960-5966. doi:10.1021/es070298u

49. Hossain M, Williams PN, Mestrot A et al (2012) Spatial heterogeneity and kinetic regulation of arsenic dynamics in mangrove sediments: the Sundarbans, Bangladesh. Environ Sci Technol 46:8645-8652. doi:10.1021/ es301328r

50. Neumann RB, Ashfaque KN, Badruzzaman AB et al (2009) Anthropogenic influences on groundwater arsenic concentrations in Bangladesh. Nat Geosci 3:46-52. doi:10.1038/ngeo685

51. Mailloux BJ, Trembath-Reichert E, Cheung J et al (2013) Advection of surface-derived organic carbon fuels microbial reduction in Bangladesh groundwater. Proc Natl Acad Sci 110:5331-5335. doi:10.1073/ pnas. 1213141110

52. Lawson M, Polya DA, Boyce AJ et al (2016) Tracing organic matter composition and distribution and its role on arsenic release in shallow Cambodian groundwaters. Geochim Cosmochim Acta 178:160-177. doi:10.1016/j.gca.2016.01.010

\section{Submit your manuscript to a SpringerOpen ${ }^{\circ}$ journal and benefit from:}

- Convenient online submission

- Rigorous peer review

- Open access: articles freely available online

- High visibility within the field

- Retaining the copyright to your article

Submit your next manuscript at $\gg$ springeropen.com 